\title{
Layered transition-metal hydroxides for alkaline hydrogen evolution reaction
}

\author{
Qianfeng Liu a,b, Erdong Wang a,*, Gongquan Sun a,\# \\ a Division of Fuel Cell \& Battery, Dalian National Laboratory for Clean Energy, Dalian Institute of Chemical Physics, Chinese Academy of Sciences, Dalian \\ 116023, Liaoning, China \\ b University of Chinese Academy of Sciences, Beijing 100049, China
}

\section{A R T I C L E I N F 0}

\section{Article history:}

Received 30 September 2019

Accepted 22 October 2019

Published 5 April 2020

\section{Keywords:}

Transition-metal hydroxides

Hydrogen evolution reaction

Water splitting

Electrocatalysis

Synergistic effect

\begin{abstract}
A B S T R A C T
Hydrogen is a promising sustainable energy to replace fossil fuels owning to its high specific energy and environmental friendliness. Alkaline water electrolysis has been considered as one of the most prospective technologies for large scale hydrogen production. To boost the sluggish kinetics of hydrogen evolution reaction (HER) in alkaline media, abundant materials have been designed and fabricated. Herein, we summarize the key achievements in the development of layered transition-metal hydroxides $\left[\mathrm{TM}(\mathrm{OH})_{x}\right]$ for efficient alkaline HER. Based on the structure of TM $(\mathrm{OH})_{x}$, the mechanism of synergistic effect between TM(OH) $)_{x}$ and HER active materials is illuminated firstly. Then, recent progress of TM(OH) $)_{x}$-based HER catalysts to optimize the synergistic effect are categorized as $\mathrm{TM}(\mathrm{OH})_{x}$ and active materials, including species, structure, morphology and interaction relationship. Furthermore, $\mathrm{TM}(\mathrm{OH})_{x}$-based overall water splitting electrocatalysts and electrodes are summarized in the design principles for high activity and stability. Finally, some of key challenges for further developments and applications of hydrogen production are proposed.
\end{abstract}

(C) 2020, Dalian Institute of Chemical Physics, Chinese Academy of Sciences. Published by Elsevier B.V. All rights reserved.

\section{Introduction}

With the global increasing demand of energy and enhancing of environmental awareness, exploiting renewable and low-carbon energy supply is inevitable for the sustainable society [1,2]. Hydrogen, as an ideal energy carrier, has been proposed as a promising alternative for fossil fuels because of its characteristic of clean product and high specific energy $[3,4]$. One of the efficient scenarios for hydrogen production without $\mathrm{CO}_{2}$ releasing is combining water electrolysis with renewable energy sources, such as solar and wind energy $[5,6]$. However, the cost of hydrogen production from water electrolysis is relative higher than that from fossil fuels (e.g. steam reforming) because of the high HER overpotential to some extent, which limited the large-scale applications of water electrolysis [5]. Therefore, enormous studies have been devoted to discover and fabricate effective HER catalysts and electrodes materials to reduce the cost of hydrogen production from water electrolysis $[4,7-10]$.

The mechanism of electrocatalytic HER is varied with the condition of electrolyte, especially for $\mathrm{pH}$ value. In acidic media, the Volmer reaction is the reduction of proton (Eq. (1)), while

\footnotetext{
* Corresponding author. Tel/Fax: +86-411-84379216; E-mail: edwang@dicp.ac.cn

\# Corresponding author. Tel: +86-411-84379240; Fax: +86-411-84379600; E-mail: gqsun@dicp.ac.cn

This work was supported by the National Key Research and Development Program (2017YFC0306403), the Strategic Priority Research Program of the Chinese Academy of Sciences (XDA09030104, XDA22010601) and the Youth Innovation Promotion Association of the Chinese Academy of Sciences.

DOI: S1872-2067(19)63458-3 | http://www.sciencedirect.com/science/journal/18722067 | Chin. J. Catal., Vol. 41, No. 4, April 2020
} 
in alkaline media, it changes to the reduction of water molecule (Eq. (2)).

$$
\begin{array}{cc}
\mathrm{H}^{+}+\mathrm{M}+\mathrm{e}^{-} \rightarrow{\mathrm{M}-\mathrm{H}^{*}}^{\mathrm{H}} & \text { (acidic media) } \\
\mathrm{H}_{2} \mathrm{O}+\mathrm{M}+\mathrm{e}^{-} \rightarrow \mathrm{M}-\mathrm{H}^{*}+\mathrm{OH}^{-} & \text {(alkaline media) }
\end{array}
$$

The different reaction mechanisms greatly alter the electrocatalytic activity via changing the kinetic and thermodynamic properties [11]. For example, the HER catalytic activity of $\mathrm{Pt}$ at $\mathrm{pH}=13$ is about 2 to 3 orders of magnitude lower than that of $\mathrm{pH}=1$ [12]. For water electrolysis, however, it is better to operate in alkaline condition, because the materials in alkaline media are always more corrosion-resistant than in acidic media. It helps to sharply reduce the facility cost via using steel and nickel as the electrodes of alkaline water electrolysis. Additionally, the alkaline media is more beneficial for electrocatalytic activity and stability of the oxygen evolution reaction (OER), the other half reaction of water electrolysis [12,13]. For example, the OER catalysts in alkaline condition can remove Ir-based materials to reduce the cost $[3,6]$. Therefore, enhancing the HER electrocatalytic performance in alkaline condition is particularly significant to the development of water electrolysis for hydrogen production.

Recently, a variety of HER catalysts have been explored to promote the electrocatalytic performance in alkaline condition, including noble metals [14-16], alloys [17], transition metal oxides [11], hydroxides [18,19], sulfides [20,21], nitrides [22], phosphides [8,23], carbides [24] and the hybrid materials $[4,13]$. For these materials, their basic strategies for reducing the HER overpotential are surround with enhancing the electrocatalytic activity, enlarging the reactive sites/area, improving the electroconductivity, and ameliorating the bubble or gas transport. Notably, the methods of enhancing the electrocatalytic activity of HER have already been the focus. However, compared with HER in acid, the mechanism of HER in alkaline condition is more complex. For example, the Volmer step (Eq. 2) not only relates to the adsorption energy of the hydrogen atom but also involves the adsorption energy of water, the dissociation energy of the $\mathrm{H}-\mathrm{OH}$ band of water molecule and the desorption energy of the hydroxide anion $[25,26]$. The complex reactions make it difficult for the electrocatalysts (composed with single component) to catalyze all the reaction steps efficiently, even though the noble metals. Therefore, a variety of hybrid materials have been exploited, each component of which was designed to catalyze the target reaction step or steps and work together to boost the complex reactions efficiently with synergistic effect. Especially, transition metal hydroxide-based hybrids exhibited excellent HER performance, such as the $\mathrm{Ni}(\mathrm{OH})_{2}$ modified $\mathrm{Pt}$ [27] and $\mathrm{CuS}$ coated with $\mathrm{Ni}(\mathrm{OH})_{2}$ [28].

At present, tremendous hybrid $\mathrm{TM}(\mathrm{OH})_{x}$ materials have been exploited and investigated for HER, however, a comprehensive review on this topic has not been published. Herein, this review summarizes the key achievements in the development of layered transition-metal hydroxides $\left[\mathrm{TM}(\mathrm{OH})_{x}\right]$ for efficient alkaline HER. Based on the structure of TM(OH $)_{x}$, the mechanism of synergistic effect between TM(OH) $)_{x}$ and HER active materials is illuminated firstly. Then, recent progress of $\mathrm{TM}(\mathrm{OH})_{x}$-based HER catalysts to optimize the synergistic effect are categorized as $\mathrm{TM}(\mathrm{OH})_{x}$ and active materials, including species, structure, morphology and interaction relationship. Furthermore, $\mathrm{TM}(\mathrm{OH})_{x}$-based overall water splitting electrocatalysts and electrodes are summarized in the design principles for high activity and stability. Finally, some of key challenges for further developments and applications of hydrogen production are proposed.

\section{Structure of $\mathrm{TM}(\mathrm{OH})_{x}$}

According to the reports, TM(OH) $)_{x}$ for HER are mainly focused on Ni-, Co- and Fe-based hydroxides, including layered single and double hydroxides with the structure of brucite-type hydroxides $\left[\mathrm{Mg}(\mathrm{OH})_{2}\right]$ [29]. This structure consists of the metal ions approximately octahedrally surrounded by hydroxide ions. It should be pointed out that $\mathrm{Ni}(\mathrm{OH})_{2}$ is one of typical brucite-type structures and widely used for HER, which is introduced as the example. Generally, the $\mathrm{Ni}(\mathrm{OH})_{2}$ exhibits two common forms of $\alpha$ - and $\beta-\mathrm{Ni}(\mathrm{OH})_{2}$ [30]. Compared with $\alpha-\mathrm{Ni}(\mathrm{OH})_{2}$, the $\beta-\mathrm{Ni}(\mathrm{OH})_{2}$ is more stable because of the less disorders. For the brucite-type structure of $\beta-\mathrm{Ni}(\mathrm{OH})_{2}$, the angle between $a$ - and $b$-axes, namely $\gamma$, is $120^{\circ}$ as shown in Fig. 1(a), and the values of $a, b$ and $c$ are $0.31,0.31$ and $0.46 \mathrm{~nm}$, respectively (Fig. $1(\mathrm{~b})$ ). The $\alpha-\mathrm{Ni}(\mathrm{OH})_{2}$ has the same $a b$-plane layered structure with $\beta-\mathrm{Ni}(\mathrm{OH})_{2}$, however, it always consists of abundant positive charged $\mathrm{Ni}(\mathrm{OH})_{2-x}$ layers. To restore charge neutrality, its interlayer space is always intercalated with anions and water molecules [31], broadening its interlayer distance ranges from 0.41 to $0.80 \mathrm{~nm}$ [32]. Fig. 1(c), (d) show one of the idealized $\alpha-\mathrm{Ni}(\mathrm{OH})_{2}$ structures which only contains the water molecules in the interlayer [33]. These intercalated waters are only weakly associated with the nickel cations, but not form hydrogen bonds with the lattice hydroxides [34].

The nature structure of $\mathrm{Ni}(\mathrm{OH})_{2}$ makes it possess some unique properties, such as hydration, ionic intercalation and substitution [35]. Because of hydration, water molecules insert into the interlayer space of the $\mathrm{Ni}(\mathrm{OH})_{2}$ sheets, the lattice en-

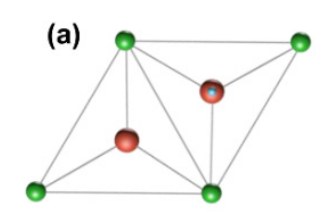

(b)
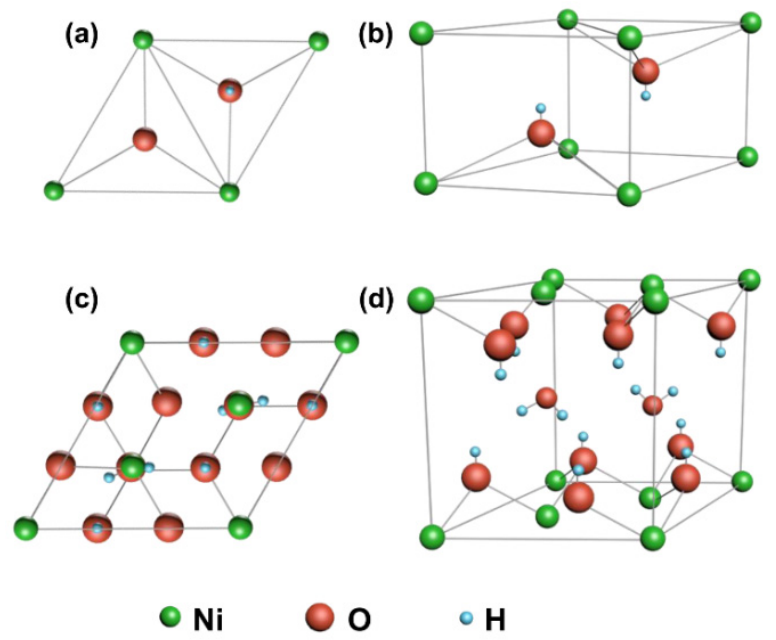

d) $\mathrm{C}$

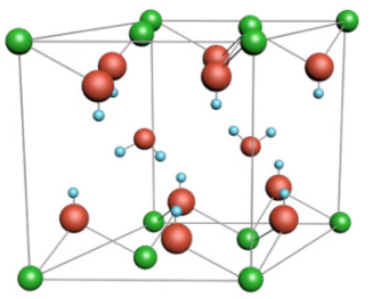

$\circ \mathbf{H}$

Fig. 1. The crystal structure of $\beta-\mathrm{Ni}(\mathrm{OH})_{2}$ by unit cell projection (a) and unit cell (b). The idealized crystal structure of $\alpha-\mathrm{Ni}(\mathrm{OH})_{2} \cdot \mathrm{xH}_{2} \mathrm{O}$ by unit cell projection (c) and unit cell (d). 
ergy of $\mathrm{Ni}(\mathrm{OH})_{2}$ decreases, meanwhile, the interlayer distance increases. These results weaken the force of adjacent layers and enhance the electrochemistry activity of the $\mathrm{Ni}(\mathrm{OH})_{2}$ when it acted as the alkaline battery material. With the help of ionic intercalation, the interlayer distance can be further expanded. When the appropriate intercalated reagents, such as sodium dodecyl sulfate [36] and hexamethylenetetramine [37], combined with particular reaction conditions [38], the $\mathrm{Ni}(\mathrm{OH})_{2}$ sheets can be peeled to single $[36,39,40]$ or several designed layers [41-44] to be similar with the graphene and $\mathrm{MoS}_{2}$ $[45,46]$. For the ionic substitution property, Ni(II) can be substituted by the other metal cations to form isostructural hydroxides of $\mathrm{Ni}(\mathrm{OH})_{2}$, such as NiFe-LDH, NiCo-LDH, which were widely applied for electrocatalyst [47-51] and energy storage materials [52-55]. Own to the properties as described above, the structure of $\mathrm{Ni}(\mathrm{OH})_{2}$ is always disordered and multitudinous, making it hard to be simply designated as $\alpha$ - or $\beta$-phase.

The electrochemical performance of $\mathrm{Ni}(\mathrm{OH})_{2}$-based materials are usually varied with the crystal forms, thickness and cation substitution. For example, $\alpha-\mathrm{Ni}(\mathrm{OH})_{2}$ displays higher activity for oxygen reduction reaction (ORR) than that of $\beta-\mathrm{Ni}(\mathrm{OH})_{2}$ [31], caused by the more disordered or defected structure as similar to other 2D materials, such as $\mathrm{MoS}_{2}$ and graphene [56-58]. Additionally, the thickness of the $\mathrm{Ni}(\mathrm{OH})_{2}$ nanosheets is one of main factors to change the electrochemical activity of the hybrid materials. For instance, the binding energy of hydroxide $[\mathrm{BE}(\mathrm{OH})]$ of single-layer $(\mathrm{SL}) \mathrm{Ni}(\mathrm{OH})_{2}$ is more negative than that of multi-layer $(\mathrm{ML}) \mathrm{Ni}(\mathrm{OH})_{2}$, resulting in higher HER activity of SL-Ni(OH $)_{2}$ modified Pt/C electrocatalyst than that of $\mathrm{ML} \mathrm{Ni(OH)} 2$ [39]. To further enhance the electrocatalytic activity, cation substitution to form LDH [29,33,59] is one of common and valid strategies by changing the physical and chemical properties of the materials. However, more convincing proofs under atomic level are needed to understand these phenomena [9]. Fortunately, some researchers have been trying to explain the mechanism of the enhanced activity of the cation substitution materials for HER in alkaline condition by density functional theory (DFT) [60].

The other layered $\mathrm{TM}(\mathrm{OH})_{x}$ for HER would be described simply, such as $\mathrm{Co}(\mathrm{OH})_{2}$ and LDHs, because they have the similar structure with $\mathrm{Ni}(\mathrm{OH})_{2}$. The layered $\mathrm{Co}(\mathrm{OH})_{2}$ also have two polymorphs of $\alpha$ - and $\beta-\mathrm{Co}(\mathrm{OH})_{2}$, which is similar to $\mathrm{Ni}(\mathrm{OH})_{2}$ that the $\alpha-\mathrm{Co}(\mathrm{OH})_{2}$ has a larger interlayer distance $(\geq 0.70 \mathrm{~nm})$ than that of $\beta-\mathrm{Co}(\mathrm{OH})_{2}(0.46 \mathrm{~nm})$ because of the interlayer intercalated anions and water molecules [61]. Similarly, the $\alpha-\mathrm{Co}(\mathrm{OH})_{2}$ is also metastable and easily undergoes into $\beta-\mathrm{Co}(\mathrm{OH})_{2}$ in strongly alkaline media [62,63]. Because the $\mathrm{BE}(\mathrm{OH})$ of $\mathrm{Co}(\mathrm{OH})_{2}$ is stronger than that of $\mathrm{Ni}(\mathrm{OH})_{2}$, the $\mathrm{Co}(\mathrm{OH})_{2}$-based hybrid materials always displays lower HER activity in alkaline media than that of $\mathrm{Ni}(\mathrm{OH})_{2}$, leading to less reports. The various proportions of the di- and trivalent cations, the interlayered ions and water molecules vary LDHs with a general formula of $\left[\mathrm{M}^{\mathrm{II}_{1-x}} \mathrm{M}^{\mathrm{III}}{ }_{x}(\mathrm{OH})_{2}\right]^{x+}\left[\mathrm{A}^{n-}\right]_{x / n} \cdot y \mathrm{H}_{2} \mathrm{O}$ [29]. Consequentially, the tunable structure of the LDHs make it possible to control its physical and chemical properties, such as energy band, adsorption energy of $\mathrm{H}, \mathrm{O}$ or $\mathrm{OH}$, which are the vital activity describers for photocatalytic and electrochemical cata- lytic performance [59,64-66]. Therefore, LDHs have attracted extensive attention in the fields of electrocatalysis, photocatalysis and photoelectrocalysis $[12,18,19,38,67,68]$.

\section{Hydrogen evolution reaction}

Generally, the bulk single $\mathrm{TM}(\mathrm{OH})_{2}$, such as $\mathrm{Ni}(\mathrm{OH})_{2}$ and $\mathrm{Co}(\mathrm{OH})_{2}$, are the poor HER active materials owing to the extremely weak $\mathrm{H}$ adsorption energy [11]. However, the $\mathrm{BE}_{(\mathrm{OH})}$ are strong enough to help the dissociation of the water molecule [69]. This is one step of Volmer reaction for HER in alkaline condition which is always the rate-determining step of the HER electrocatalytic materials, such as Pt and Ni [26,70]. Therefore, when the HER electrocatalytic materials, such as noble metals, non-noble metals and the corresponding compounds, were modified with the proper $\mathrm{TM}(\mathrm{OH})_{2}$, the HER electrocatalytic activity of these hybrid materials in alkaline condition could be obviously enhanced. Additionally, the LDHs hybrid materials have also been widely reported as the HER electrocatalysts [19]. Owing to the proper $\mathrm{H}$ adsorption energy shift, even some kinds of LDHs exhibited high HER electrocatalytic activity. Herein, in this chapter, we will introduce the mechanism of activity enhanced, $\mathrm{TM}(\mathrm{OH})_{2}$ hybrid materials, LDHs and the hybrid materials for HER in alkaline media.

\subsection{Mechanism of activity enhanced}

For HER, the layered TM(OH $)_{2}$ are focused on $\mathrm{Ni}(\mathrm{OH})_{2}$ and $\mathrm{Co}(\mathrm{OH})_{2}$. According to the reported literatures, the synthesis methods of the materials may affect their activity. But for the $\mathrm{TM}(\mathrm{OH})_{2}$, even though the synthesis ways are different, including chemical precipitation, electrodeposition and hydrothermal methods, they all exhibit poor HER performance $(\eta>200 \mathrm{mV}$ at $10 \mathrm{~mA} \mathrm{~cm}^{-2}$ ) when coated on the inactive HER electrode substrates, such as glass carbon electrode, carbon cloth and titanium [28,71-78]. Notably, when the substrates changed to active HER materials, HER activity of the hybrid materials would be obviously enhanced. For example, when the nickel foam was modified with $\mathrm{Co}(\mathrm{OH})_{2}$ ultrathin nanosheet arrays, the HER current of the modified nickel foam at $200 \mathrm{mV}$ was over 10 times higher than that of both nickel foam and $\mathrm{Co}(\mathrm{OH})_{2}$ ultrathin nanosheet arrays [79].

To better understand this interesting phenomenon, firstly, we must comprehend the mechanism that the $\mathrm{TM}(\mathrm{OH})_{2}$ plays the role for the HER in alkaline condition. In 2011, Markovic's group [27] found that the HER activity of Pt(111) electrode modified with $\mathrm{Ni}(\mathrm{OH})_{2}$ clusters with height of $0.7 \mathrm{~nm}$ and width of 8-10 nm was about 7 times higher than that of Pt(111) electrode in alkaline condition, even though 35\% surface area of $\mathrm{Pt}(111)$ electrode was covered by $\mathrm{Ni}(\mathrm{OH})_{2}$ clusters. Moreover, when the $\mathrm{Ni}(\mathrm{OH})_{2} / \mathrm{Pt}(111)$ electrode changed to $\mathrm{Ni}(\mathrm{OH})_{2} / \mathrm{Pt}$-island/Pt(111), the HER activity could be further enhanced (Fig. 2). Clearly, the enhanced HER activity did owe to the modified $\mathrm{Ni}(\mathrm{OH})_{2}$ clusters. The authors suggested that $\mathrm{Ni}(\mathrm{OH})_{2}$ promoted water dissociation and the concomitant interaction (the rate-determining step of Volmer reaction) to boost the formation rate of adsorption hydrogen atom inter- 

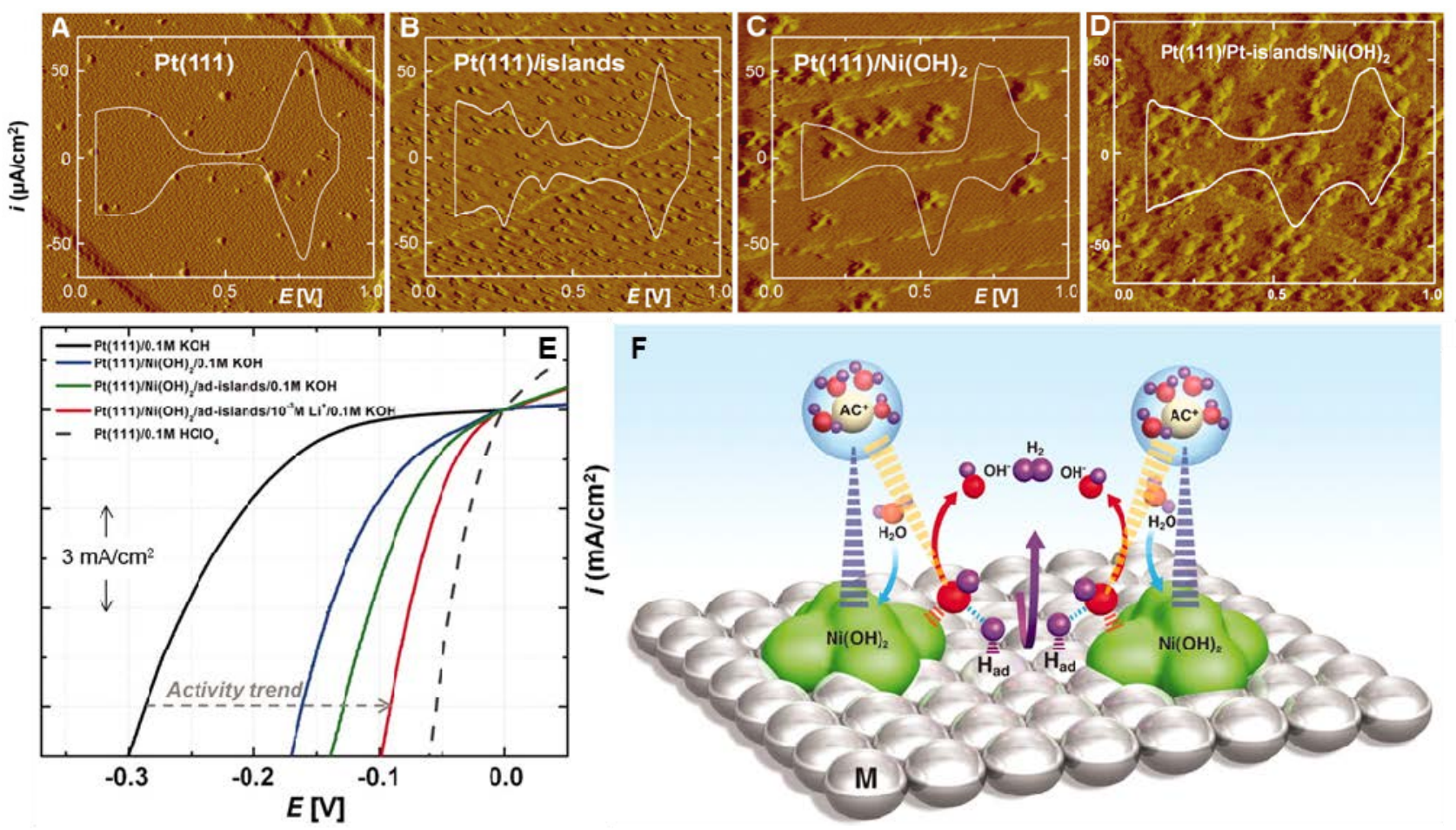

Fig. 2. STM images $(60 \mathrm{~nm} \times 60 \mathrm{~nm})$ and $\mathrm{CV}$ traces for the electrodes of Pt(111) (A), Pt(111) with 2D Pt islands (B), Pt(111) modified with 3D Ni(OH) clusters (C) and Pt(111) with 2D Pt islands modified with 3D Ni(OH) 2 clusters (D) in $0.1 \mathrm{M} \mathrm{KOH}$ electrolyte. (E) HER activities of the electrodes of in $0.1 \mathrm{M} \mathrm{KOH} \mathrm{(a,} \mathrm{c,} \mathrm{d)} \mathrm{and} \mathrm{in} 0.1 \mathrm{M} \mathrm{KOH}$ electrolyte with addition of $\mathrm{Li}^{+}$cation, and $\mathrm{Pt}(111)$ in $0.1 \mathrm{M} \mathrm{HClO}_{4}$ (d). (F) Schematic representation of water dissociation [27]. Copyright (2011) The American Association for the Advancement of Science.

mediates on the Pt surface, which was named as bi-functional mechanism. As schematically depicted in Fig. 2f, firstly, the water molecule is adsorbed at the boundary between $\mathrm{Ni}(\mathrm{OH})_{2}$ and $\mathrm{Pt}$ domains via concerted interaction of $\mathrm{O}$ atoms with $\mathrm{Ni}(\mathrm{OH})_{2}$ and $\mathrm{H}$ atoms with Pt. Then, with the help of tailor effect of $\mathrm{Ni}(\mathrm{OH})_{2}$, the adsorbed water is dissociated more easily. Following, hydrogen is adsorbed on the nearby vacant Pt sites while $\mathrm{OH}$ on the $\mathrm{Ni}(\mathrm{OH})_{2}$. Finally, two adsorption hydrogen atoms on the Pt recombine to form $\mathrm{H}_{2}$ while $\mathrm{OH}^{-}$desorbs from the $\mathrm{Ni}(\mathrm{OH})_{2}$, followed by the new repeated cycle of adsorption water molecule on the same site [27].

To further confirm the bi-functional mechanism, Markovic and co-workers [80] modified $\mathrm{Pt}(111)$ electrodes with different $\mathrm{TM}(\mathrm{OH})_{2}$ [e.g. $\mathrm{Ni}(\mathrm{OH})_{2}, \mathrm{Co}(\mathrm{OH})_{2}, \mathrm{Fe}^{2+\delta} \mathrm{O}^{\delta}(\mathrm{OH})_{2-\delta}$ and $\mathrm{Mn}(\mathrm{OH})_{2}$ ] and decorated different electrode substrates (e.g. Pt, $\mathrm{Au}$ and $\mathrm{Ni}$ ) with $\mathrm{Ni}(\mathrm{OH})_{2}$. As a result, the $\mathrm{OH}_{\mathrm{ad}}-\mathrm{TM}^{2+\delta}$ bond strength can be controlled by the species of $\mathrm{TM}(\mathrm{OH})_{2}$ with the bond strength order of $\mathrm{Ni}(\mathrm{OH})_{2}<\mathrm{Co}(\mathrm{OH})_{2}<\mathrm{Fe}^{2+\delta} \mathrm{O}^{\delta}(\mathrm{OH})_{2-\delta}<\mathrm{Mn}(\mathrm{OH})_{2}$. This order is just opposite with the HER activities, namely, the most active electrode is $\mathrm{Ni}(\mathrm{OH})_{2} / \mathrm{Pt}(111)$ and the least is $\mathrm{Mn}(\mathrm{OH})_{2} / \mathrm{Pt}(111)$. The HER activity and the $\mathrm{OH}_{\mathrm{ad}}-\mathrm{TM}^{2+\delta}$ bond strength trend indicates that there must be a balance between the transition state energy of water dissociation and the final state energy of adsorbed $\mathrm{OH}_{\mathrm{ad}}-\mathrm{M}^{2+\delta} \mathrm{O}^{\delta}(\mathrm{OH})_{2-\delta}$. Namely, the modified $\mathrm{TM}(\mathrm{OH})_{2}$ must balance the facilitating water dissociation and preventing "poisoning" with the water dissociation product together with the optimal $\mathrm{Pt}-\mathrm{H}_{\mathrm{ad}}$ energetics [80]. To expand the universality of this bi-functional mechanism, they also observed the similar phenomenon on HER when the IB, Pt and $3 \mathrm{~d}$ TMs group metals modified with $\mathrm{Ni}(\mathrm{OH})_{2}$ clusters. Especially for Ni electrode, the HER activity was enhanced about four times when modified with $\mathrm{Ni}(\mathrm{OH})_{2}$ clusters [81]. Although this bi-functional mechanism is reasonable to explain this phenomenon, as the HER electrocatalyst, it also need deeper and wider consideration for the complex conditions, such as structure, morphology, transport of mass and electron. For example, Koper and co-workers [26,82] owed the enhanced HER performance by modified $\mathrm{Ni}(\mathrm{OH})_{2}$ to faster mass transfer. They found that the modified $\mathrm{Ni}(\mathrm{OH})_{2}$ can reorganize the interfacial water network to reduce the proton/hydroxide transfer barrier, thereby shifting the potential of zero (free) charge toward the HER equilibrium potential in alkaline condition to enhance HER activity. Additionally, the metal/metal oxide interface (e.g. $\mathrm{Ni} / \mathrm{NiO}, \mathrm{Ni} / \mathrm{CeO}_{2}$ ) can also enhance HER activity in alkaline media via the similar bi-functional mechanism [83-85], but the metal oxide system is beyond the scope of this review.

\section{2. $\mathrm{TM}(\mathrm{OH})_{2}$ hybrid materials}

The electrochemical performance of the $\mathrm{TM}(\mathrm{OH})_{2}$ hybrid materials is always based on each component, that is, $\mathrm{TM}(\mathrm{OH})_{2}$ and active materials of HER. For TM(OH)2, mainly including the species, type of crystal structure, thickness and content. But for active materials, it mainly refers to the intrinsic activity, exposed active area/sites, conductivity and the interaction relationship with $\mathrm{TM}(\mathrm{OH})_{2}$, determined by the species and structure of the active materials. The results are summarized in Table 1. 
Table 1

Summary of recent reported TM(OH $)_{2}$ and LDHs hybrid materials for HER.

\begin{tabular}{|c|c|c|c|c|c|}
\hline Material & Method & Overpotential & Tafel slope $/ \mathrm{mV} \mathrm{Dec}{ }^{-1}$ & Electrolyte & Ref. \\
\hline $\mathrm{Pt} / \mathrm{C}-\mathrm{SL} \mathrm{Ni}(\mathrm{OH})_{2} 20 \%$ & Hydrothermal & $157 \mathrm{mV}$ at $5 \mathrm{~mA} \mathrm{~cm}^{-2}$ & - & $0.1 \mathrm{M} \mathrm{KOH}$ & [39] \\
\hline $\mathrm{Pt} / \mathrm{C}-\mathrm{Ni}(\mathrm{OH})_{2} 10 \%$ & Deposition & $50 \mathrm{mV}$ at $5.5 \mathrm{~mA} \mathrm{~cm}^{-2}$ & - & $0.1 \mathrm{M} \mathrm{KOH}$ & [89] \\
\hline $\mathrm{Pt}-\mathrm{Co}(\mathrm{OH})_{2} / \mathrm{CC}$ & Hydrothermal \& electrodeposition & $32 / 122 \mathrm{mV}$ at $10 / 100 \mathrm{~mA} \mathrm{~cm}^{-2}$ & 70 & $1 \mathrm{M} \mathrm{KOH}$ & {$[72]$} \\
\hline Pt NPs/ SL Ni(OH) $)_{2}$ & \multirow{2}{*}{ Hydrothermal } & $70 \mathrm{mV}$ at $11.2 \mathrm{~mA} \mathrm{~cm}^{-2}$ & & \multirow{2}{*}{$0.1 \mathrm{M} \mathrm{KOH}$} & \multirow{2}{*}[40]{} \\
\hline Pt NWs/ SL Ni(OH) $)_{2}$ & & $70 \mathrm{mV}$ at $25.6 \mathrm{~mA} \mathrm{~cm}^{-2}$ & - & & \\
\hline$\alpha-\mathrm{Ni}(\mathrm{OH})_{2} / \mathrm{Pt}$ & \multirow{2}{*}{ Hydrothermal for $\mathrm{Ni}(\mathrm{OH})_{2}$} & $124 \mathrm{mV}$ at $10 \mathrm{~mA} \mathrm{~cm}^{-2}$ & 48 & \multirow{2}{*}{$0.1 \mathrm{M} \mathrm{KOH}$} & \multirow{2}{*}{ [88] } \\
\hline$\beta-\mathrm{Ni}(\mathrm{OH})_{2} / \mathrm{Pt}$ & & $92 \mathrm{mV}$ at $10 \mathrm{~mA} \mathrm{~cm}^{-2}$ & 42 & & \\
\hline $\mathrm{Ni}(\mathrm{OH})_{2} / \mathrm{Pt}(111)$ & Electrodeposition & $\sim 170 \mathrm{mV}$ at $12 \mathrm{~mA} \mathrm{~cm}^{-2}$ & - & $0.1 \mathrm{M} \mathrm{KOH}$ & [27] \\
\hline $\mathrm{Pd} / \mathrm{Ni}(\mathrm{OH})_{2} / \mathrm{NF}$ & Hydrothermal & $193 \mathrm{mV}$ at $100 \mathrm{~mA} \mathrm{~cm}^{-2}$ & 41 & $1 \mathrm{M} \mathrm{NaOH}$ & [103] \\
\hline $\mathrm{RuO}_{2} / \mathrm{Ni}(\mathrm{OH})_{2} / \mathrm{NF}$ & $\mathrm{NaCl}$-assisted corrosion & $100 \mathrm{mV}$ at $10 \mathrm{~mA} \mathrm{~cm}^{-2}$ & - & $1 \mathrm{M} \mathrm{KOH}$ & [133] \\
\hline $\mathrm{Pt}-\mathrm{Ni}(\mathrm{OH})_{2} / \mathrm{NF}$ & Acid-Etching & $37 \mathrm{mV}$ at $10 \mathrm{~mA} \mathrm{~cm}^{-2}$ & 30.4 & $1 \mathrm{M} \mathrm{NaOH}$ & {$[86]$} \\
\hline $\mathrm{PtO}_{2}-\mathrm{Ni}(\mathrm{OH})_{2} / \mathrm{Ti}$ & Hydrothermal & $31.4 \mathrm{mV}$ at $4 \mathrm{~mA} \mathrm{~cm}^{-2}$ & 89 & $0.1 \mathrm{M} \mathrm{KOH}$ & [73] \\
\hline $\mathrm{Ni} / \mathrm{Ni}(\mathrm{OH})_{2} / \mathrm{Pd} / \mathrm{rGO}$ & Hydrothermal & $150 \mathrm{mV}$ at $9 \mathrm{~mA} \mathrm{~cm}^{-2}$ & 70 & $0.1 \mathrm{M} \mathrm{KOH}$ & {$[74]$} \\
\hline rNGO/Au-LaNi-LDH & Sonochemical method & $80 \mathrm{mV}$ at $10 \mathrm{~mA} \mathrm{~cm}^{-2}$ & 60 & $0.5 \mathrm{M} \mathrm{H}_{2} \mathrm{SO}_{4}$ & [134] \\
\hline $\mathrm{Co}(\mathrm{OH})_{2} @ \mathrm{PANI}$ & Electrodeposition & $88 \mathrm{mV}$ at $10 \mathrm{~mA} \mathrm{~cm}^{-2}$ & 91.6 & $1.0 \mathrm{M} \mathrm{NaOH}$ & [135] \\
\hline $\mathrm{Co}(\mathrm{OH})_{2} / \mathrm{MECN}$ & Hydrothermal & $69.2 \mathrm{mV}$ at $10 \mathrm{~mA} \mathrm{~cm}^{-2}$ & 61.9 & $1 \mathrm{M} \mathrm{KOH}$ & [136] \\
\hline \multirow{2}{*}{$\mathrm{Co}(\mathrm{OH})_{2} / \mathrm{NF}$} & \multirow{2}{*}{ Electrodeposition \& cathodic reaction } & $46 \mathrm{mV}$ at $10 \mathrm{~mA} \mathrm{~cm}^{-2}$ & 85 & $1 \mathrm{M} \mathrm{KOH}$ & \multirow{2}{*}{ [79] } \\
\hline & & $70 \mathrm{mV}$ at $10 \mathrm{~mA} \mathrm{~cm}^{-2}$ & 97 & $1 \mathrm{M} \mathrm{PB}$ & \\
\hline $\mathrm{Ni} / \mathrm{Ni}(\mathrm{OH})_{2}$ & Electrodeposition & $\sim 160 \mathrm{mV}$ at $10 \mathrm{~mA} \mathrm{~cm}^{-2}$ & - & $1 \mathrm{M} \mathrm{KOH}$ & [110] \\
\hline $\mathrm{Ni}(\mathrm{OH})_{2} / \mathrm{Ni} / \mathrm{Ti}$ & Electrodeposition & $200 \mathrm{mV}$ at $10 \mathrm{~mA} \mathrm{~cm}^{-2}$ & 88 & $1 \mathrm{M} \mathrm{KOH}$ & [111] \\
\hline $\mathrm{Ni}(\mathrm{OH})_{2} / \mathrm{NiCu}$ & Electrochemical method & $200 \mathrm{mV}$ at $19 \mathrm{~mA} \mathrm{~cm}^{-2}$ & - & $1 \mathrm{M} \mathrm{KOH}$ & [109] \\
\hline $\mathrm{Ni}(\mathrm{OH})_{2}-\mathrm{CuS}$ & Hydrothermal & $95 \mathrm{mV}$ at $10 \mathrm{~mA} \mathrm{~cm}^{-2}$ & 104 & $1 \mathrm{M} \mathrm{KOH}$ & [28] \\
\hline $\mathrm{Ni}(\mathrm{OH})_{2}-\mathrm{NiN}_{3} / \mathrm{Ti}$ & Hydrothermal & $72 \mathrm{mV}$ at $20 \mathrm{~mA} \mathrm{~cm}^{-2}$ & 86 & $1 \mathrm{M} \mathrm{KOH}$ & [121] \\
\hline $\mathrm{Ni}(\mathrm{OH})_{2}-\mathrm{Fe}_{2} \mathrm{P} / \mathrm{Ti}$ & Electrodeposition & $76 \mathrm{mV}$ at $10 \mathrm{~mA} \mathrm{~cm}^{-2}$ & 105 & $1 \mathrm{M} \mathrm{KOH}$ & [120] \\
\hline $\mathrm{Ni}(\mathrm{OH})_{2}-\mathrm{NiS}_{2} / \mathrm{Ti}$ & Electrodeposition & $90 \mathrm{mV}$ at $10 \mathrm{~mA} \mathrm{~cm}^{-2}$ & 89 & $1 \mathrm{M} \mathrm{KOH}$ & [117] \\
\hline $\mathrm{Ni}(\mathrm{OH})_{2} / \mathrm{MoS}_{2} / \mathrm{CC}$ & Hydrothermal \& electrodeposition & $80 \mathrm{mV}$ at $10 \mathrm{~mA} \mathrm{~cm}^{-2}$ & 60 & $1 \mathrm{M} \mathrm{KOH}$ & [77] \\
\hline $2 \mathrm{D}-\mathrm{MoS}_{2} / \mathrm{Co}(\mathrm{OH})_{2}$ & Hydrothermal & $128 \mathrm{mV}$ at $10 \mathrm{~mA} \mathrm{~cm}^{-2}$ & 76 & $1 \mathrm{M} \mathrm{KOH}$ & [87] \\
\hline NiCo-LDH/NF & Hydrothermal & $222 \mathrm{mV}$ at $10 \mathrm{~mA} \mathrm{~cm}^{-2}$ & 130 & $0.5 \mathrm{M} \mathrm{H}_{2} \mathrm{SO}_{4}$ & [124] \\
\hline $\mathrm{CoW}(\mathrm{OH})_{x} / \mathrm{NF}$ & Electrodeposition & $73.6 \mathrm{mV}$ at $10 \mathrm{~mA} \mathrm{~cm}^{-2}$ & 150 & $1 \mathrm{M} P B$ & [129] \\
\hline $\mathrm{NiCo}-\mathrm{OH} / \mathrm{NF}$ & Electrodeposition & $77 \mathrm{mV}$ at $10 \mathrm{~mA} \mathrm{~cm}^{-2}$ & 94 & $1 \mathrm{M} \mathrm{KOH}$ & [123] \\
\hline $\mathrm{NiCo}-\mathrm{OH} / \mathrm{C}$ & Water-in-oil synthesis & $\sim 375 \mathrm{mV}$ at $10 \mathrm{~mA} \mathrm{~cm}^{-2}$ & $\sim 120$ & $0.1 \mathrm{M} \mathrm{NaOH}$ & [122] \\
\hline $\mathrm{Ni}_{3} \mathrm{~S}_{2}-\mathrm{NiOOH} / \mathrm{NF}$ & Cyclic voltammetry & onset overpotential of $100 \mathrm{mV}$ & 98 & $1 \mathrm{M} \mathrm{KOH}$ & [137] \\
\hline
\end{tabular}

\subsection{1. $\mathrm{TM}(\mathrm{OH})_{2}$}

\subsubsection{Species}

Different kind of $\mathrm{TM}(\mathrm{OH})_{2}$ with diverse binding energy to $\mathrm{OH}$, which plays the decisive role for HER activity according to the bi-functional mechanism. In 2012, Markovic's group [80] found that $\mathrm{Ni}(\mathrm{OH})_{2}$ and $\mathrm{Co}(\mathrm{OH})_{2}$ could enhance the HER activity of $\mathrm{Pt}(111)$, and $\mathrm{Ni}(\mathrm{OH})_{2}$ exhibited better performance because of the proper bond strength of $\mathrm{OH}$. After that, the later researches focused on these two kind of $\mathrm{TM}(\mathrm{OH})_{2}$, especially for $\mathrm{Ni}(\mathrm{OH})_{2}$. For instance, Yang et al. [72] designed carbon cloth-supported $\mathrm{Co}(\mathrm{OH})_{2}$ nanosheets array as the substrate for Pt electrodeposition [Pt- $\mathrm{Co}(\mathrm{OH})_{2} / \mathrm{CC}$ ] to achieve high performance of HER with the load of Pt about $5.7 \mathrm{wt} \%$ to $\mathrm{Co}(\mathrm{OH})_{2}$. The Pt-Co(OH $)_{2} / \mathrm{CC}$ electrode required an overpotential of 32 $\mathrm{mV}$ at $10 \mathrm{~mA} \mathrm{~cm}^{-2}$ in $1 \mathrm{M} \mathrm{KOH}$, and the current density normalized to electrochemical surface area (ECSA) was 4.8 times higher than that of commercial Pt/C/CC, which was similar to the Pt nanoparticle modified single layer $\mathrm{Ni}(\mathrm{OH})_{2}[40]$. Ho et al. [86] developed a Pt-decorated $\mathrm{Ni}(\mathrm{OH})_{2}$ nanosheets array on nickel foam $\left[\mathrm{Pt}-\mathrm{Ni}(\mathrm{OH})_{2} / \mathrm{NF}\right]$ with the similar structure to $\mathrm{Pt}-\mathrm{Co}(\mathrm{OH})_{2} / \mathrm{CC}$ via self-regulating acid-etching strategy. This electrode loaded much lower Pt $\left[<0.5 \mathrm{wt} \%\right.$ to $\left.\mathrm{Ni}(\mathrm{OH})_{2}\right]$ than that of Pt- $\mathrm{Co}(\mathrm{OH})_{2} / \mathrm{CC}$, but existed similar polarization performance to Pt-Co(OH) $)_{2} / \mathrm{CC}$ with overpotential of $37 \mathrm{mV}$ at $10 \mathrm{~mA}$ $\mathrm{cm}^{-2}$ in $1 \mathrm{M} \mathrm{KOH}$. However, some HER active materials modified with $\mathrm{Co}(\mathrm{OH})_{2}$ exhibited higher active than that of $\mathrm{Ni}(\mathrm{OH})_{2}$. For example, Zhao et al. [87] found that 2D-MoS$/ \mathrm{Co}(\mathrm{OH})_{2}$ hybrid achieved an extremely lower overpotential than that of $2 \mathrm{D}-\mathrm{MoS}_{2} / \mathrm{Ni}(\mathrm{OH})_{2}$ hybrid. Interestingly, when $\mathrm{MoS}_{2}$ was replaced with $\mathrm{WS}_{2}$, the $\mathrm{Ni}(\mathrm{OH})_{2}$ hybrid displayed higher activity than that of $\mathrm{Co}(\mathrm{OH})_{2}$ to consist with Pt.

\subsubsection{Type of crystal structure}

The difference in crystal structures and lattice parameters of $\alpha-\mathrm{Ni}(\mathrm{OH})_{2}$ and $\beta-\mathrm{Ni}(\mathrm{OH})_{2}$ changes the HER electrocatalytic activity of the hybrid material. For instance, Shi et al. [88] loaded $\alpha$ - and $\beta-\mathrm{Ni}(\mathrm{OH})_{2}$ nanostructures on Pt electrode to compare their catalytic activity and stability for HER. Combined with theoretical studies, they found that $\beta-\mathrm{Ni}(\mathrm{OH})_{2}$ was better to decorate Pt than that of $\alpha-\mathrm{Ni}(\mathrm{OH})_{2}$. In detail, $\beta-\mathrm{Ni}(\mathrm{OH})_{2}$ has a stronger interaction with the water molecule and Pt substrate than that of $\alpha-\mathrm{Ni}(\mathrm{OH})_{2}$, providing the $\beta-\mathrm{Ni}(\mathrm{OH})_{2} / \mathrm{Pt}$ electrode with more favorable sites for adsorbing water molecules and hydrogen intermediates, as well as for desorbing $\mathrm{OH}$.

\subsubsection{Thickness}

The layer number of the 2D materials determines their thickness to regulate the specific surface area and adsorption energy. For instance, Jin's group [39] compared multi-layer $\mathrm{Ni}(\mathrm{OH})_{2}\left[\mathrm{ML} \mathrm{Ni}(\mathrm{OH})_{2}\right]$ and single-layer $\mathrm{Ni}(\mathrm{OH})_{2}$-nanosheetassisted commercial Pt/C [SL Ni(OH) $2-\mathrm{Pt} / \mathrm{C}]$ for HER. As a re- 

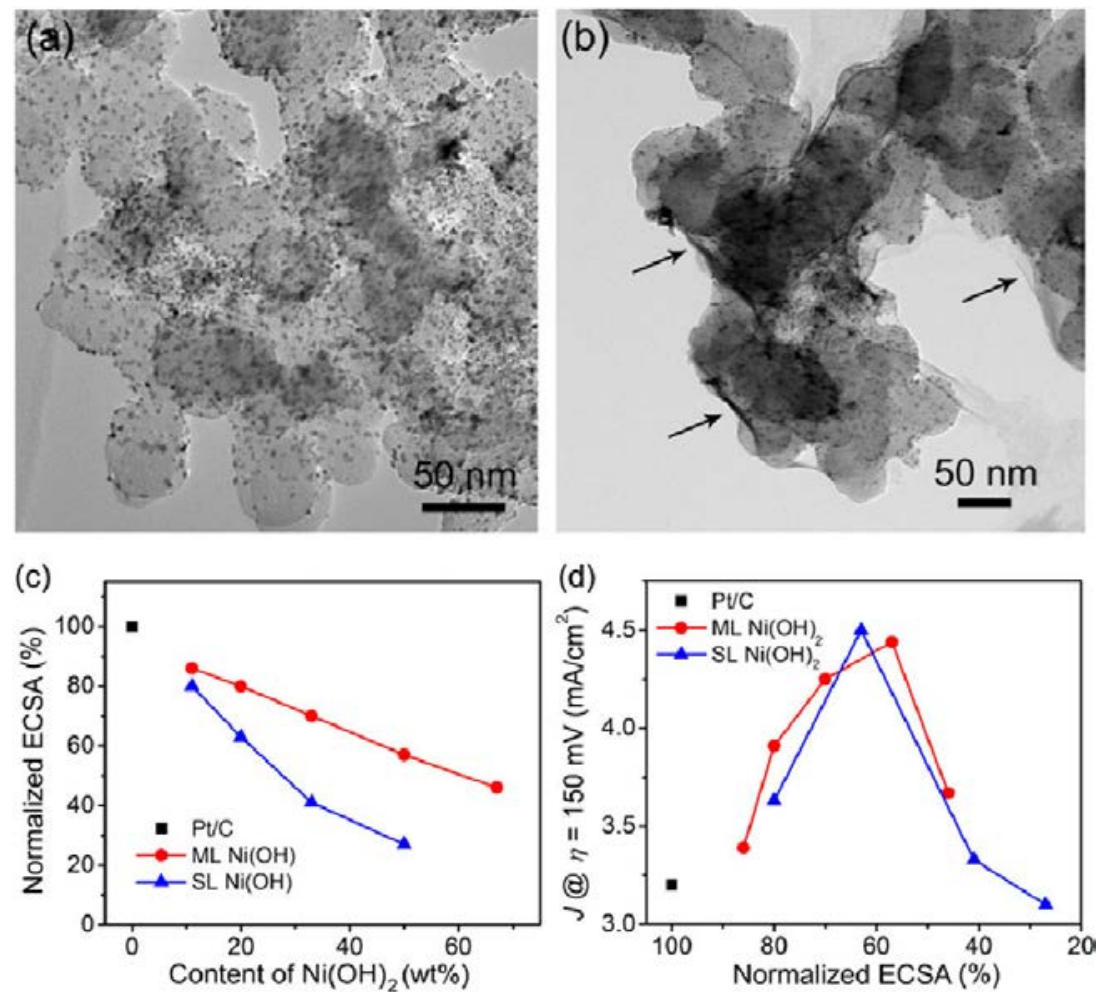

Fig. 3. TEM images of commercial Pt/C (20\% Pt) (a) and SL $\mathrm{Ni}(\mathrm{OH})_{2}-\mathrm{Pt} / \mathrm{C}$ hybrid catalyst (b). (c) Variation of normalized ECSA with different percentages of $\mathrm{Ni}(\mathrm{OH})_{2}$. (d) Plots of normalized ECSA versus current density [39]. Copyright (2015) American Chemical Society.

sult, both $\mathrm{ML} \mathrm{Ni}(\mathrm{OH})_{2}$ and $\mathrm{ML} \mathrm{Ni}(\mathrm{OH})_{2}$ can be evenly adsorbed on the surface of Pt/C nanoparticles as shown in Fig. 3(a) and

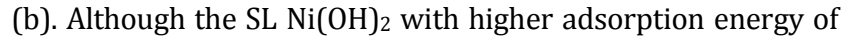
$\mathrm{OH}^{-}$and stronger interactions to the $\mathrm{Pt} / \mathrm{C}$ substrate than that of $\mathrm{ML} \mathrm{Ni(OH})_{2}$ leading to more coverage with same loading of $\mathrm{Ni}(\mathrm{OH})_{2}$ (Fig. 3(c)), the HER activity of Pt normalized ECSA is similar and the best activity occurs at $40 \%$ percent area of $\mathrm{Pt}$ covered (Fig. 3(d)). Although the thickness of $\mathrm{Ni}(\mathrm{OH})_{2}$ isn't the direct describe parameter to determine the activity of Pt, it can regulate the exposed surface area or active sites to control the electrochemical performance.

\subsubsection{Content}

The content of $\mathrm{TM}(\mathrm{OH})_{2}$ changes both coverage percent of active materials and edge area between $\mathrm{TM}(\mathrm{OH})_{2}$ and active materials, which directly decides the active area. According to the bi-functional mechanism, the enhanced HER activity is mainly provided by the $\mathrm{Pt} / \mathrm{Ni}(\mathrm{OH})_{2}$ interface determined by the content of TM(OH) 2 [27,39,81]. However, Ramani's group [89] proposed a seemingly more reasonable hypothesis that all the $\mathrm{Ni}(\mathrm{OH})_{2}$ area participated in the bi-functional mechanism but not only on the interface seemingly more reasonable. They studied the effect of the concentration of $\mathrm{Ni}(\mathrm{OH})_{2}$ to the HER activity of $\mathrm{Pt} / \mathrm{C}$. As a result, the valence of $\mathrm{Pt}$ in $\mathrm{Pt} / \mathrm{C}$ was almost the same with $\mathrm{Ni}(\mathrm{OH})_{2}$-decorated $\mathrm{Pt} / \mathrm{C}$, suggesting the intrinsic activity of Pt won't change after decorated with $\mathrm{Ni}(\mathrm{OH})_{2}$. However, the relative activity of the $\mathrm{Pt} / \mathrm{C} / \mathrm{Ni}(\mathrm{OH})_{2}$ with the $\mathrm{Ni}(\mathrm{OH})_{2}$ content of $10 \mathrm{wt} \%$ normalized to Pt ECSA increased by 2.4 times than that of $\mathrm{Pt} / \mathrm{C}$. With the increasing of $\mathrm{Ni}(\mathrm{OH})_{2}$ content, the edges between $\mathrm{Pt}$ and $\mathrm{Ni}(\mathrm{OH})_{2}$ also increased per unit area of Pt. However, the relative activity decreased slightly with the increase of $\mathrm{Pt} / \mathrm{Ni}(\mathrm{OH})_{2}$ interface, which was inconsistent with the bi-functional mechanism proposed by Markovic [27]. Therefore, all the $\mathrm{Ni}(\mathrm{OH})_{2}$ area participates in the bi-functional mechanism that is more reasonable.

\subsubsection{HER active materials}

\subsubsection{Noble metal}

Reducing usage of noble metal in the electrocatalyst is one of the effective ways to lower the cost and expand the application $[4,13,24,90,91]$. Since Markovic's group found the HER activity of $\mathrm{Pt}(111)$ can be enhanced by decorated $\mathrm{Ni}(\mathrm{OH})_{2}$, the researchers have designed extensive experiments around the loading, morphology, size and valence of Pt or other noble metals to further enhance the performance and understand the mechanism. For instance, Wang et al. [75] regulated the coverage area of Pt nanocrystals on single-layer $\mathrm{Ni}(\mathrm{OH})_{2}$ nanosheets [Pt@2D-Ni(OH $\left.)_{2}\right]$ via controlling the loading of Pt. Compared with Pt/C, all of Pt@2D-Ni(OH) 2 exhibited superior HER activity normalized to mass specific activity of Pt. Concretely, compared with the Pt coverage percentage on $\mathrm{Ni}(\mathrm{OH})_{2}$ nanosheets of $3 \%$ to $59 \%$, the activity of $94 \%$ was relative lower due to the aggregation of Pt nanocrystals and blocking of active sites as shown in Fig. 4. Additionally, Jung et al. [92] found the high Pt loading of $81.9 \mathrm{wt} \%$ equaled to $4 \mathrm{~nm}$ thick of Pt films on both side of $\mathrm{Ni}(\mathrm{OH})_{2}$ plate, reducing the HER activity to the level of commercial Pt black.

Morphology always affects the active site/area and exposed surface, while size determines specific area and even leads to 

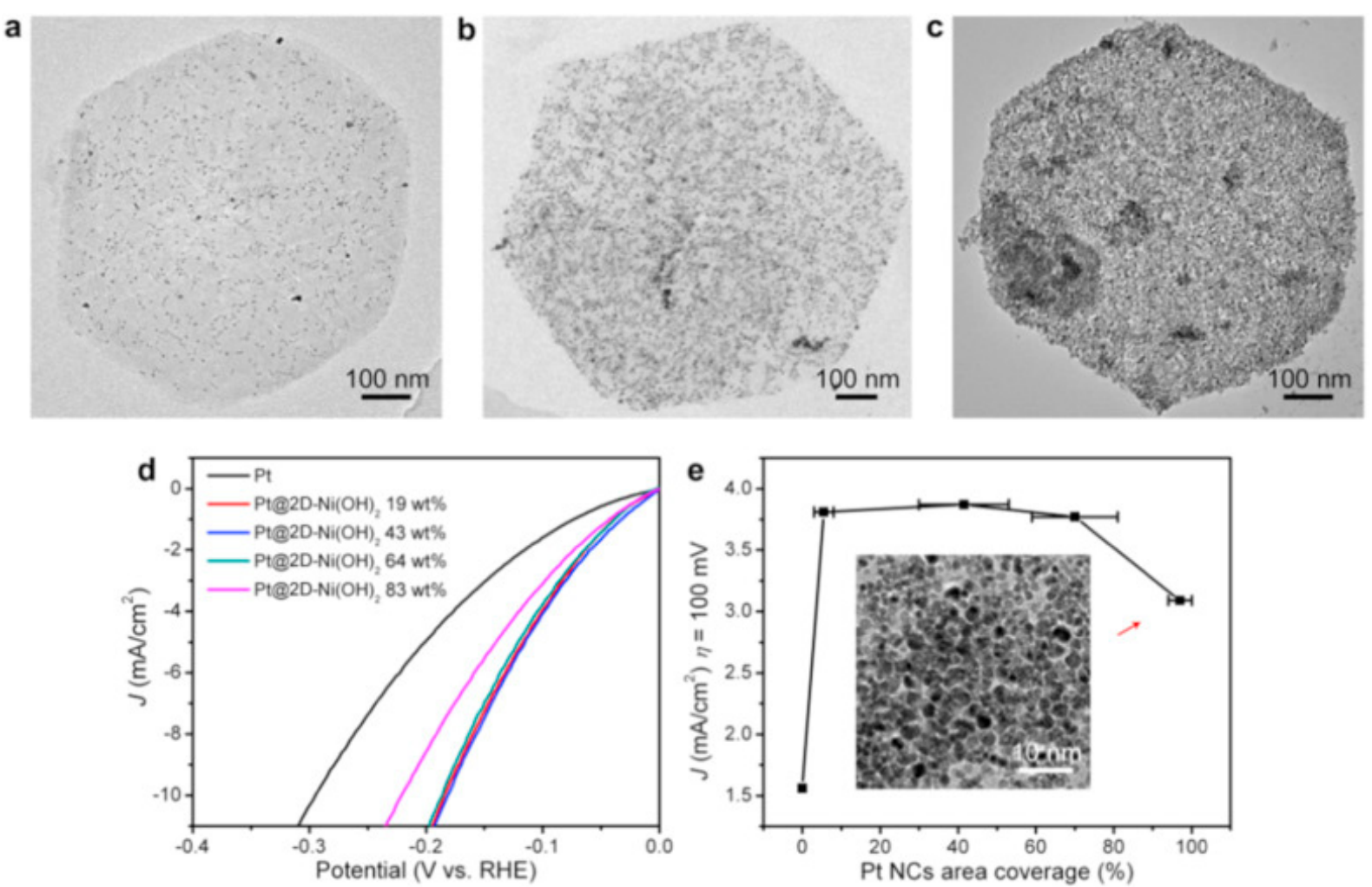

Fig. 4. TEM images of Pt@2D-Ni(OH) 2 with 19 (a), 64 (b) and 83 wt\% (c) of Pt; HER activities (d) and current density (e) versus the area coverage of Pt nanocrystals on the $\mathrm{Ni}(\mathrm{OH})_{2}$ nanosheets. The area coverage was estimated by counting the number of Pt nanoparticles and measuring the particle sizes with Pt loading of $\sim 1.13 \mu \mathrm{g} \mathrm{cm}^{-2}$ [75]. Copyright (2017) Elsevier.

the complicated "size effect". For example, Tang's group [40] compared the HER activity of Pt nanowires and nanoparticles grown on single-layered $\mathrm{Ni}(\mathrm{OH})_{2}$. Owning to the more exposed active sites and improved electrons transport characteristics of Pt nanowires, the HER performance of Pt NWs/SL-Ni(OH) 2 is more excellent than that of Pt NPs/SL-Ni(OH)2. Nevertheless, benefitting from the strong coupling between the immobilized $\mathrm{Pt}$ and the $\mathrm{Ni}(\mathrm{OH})_{2}$ nanosheets, both of Pt NWs/SL-Ni(OH $)_{2}$ and Pt NPs/SL-Ni(OH $)_{2}$ are much better than that of Pt/C and pure Pt NWs without decoration of $\mathrm{Ni}(\mathrm{OH})_{2}$ as shown in Fig. 5. To expose more active site of $\mathrm{Pt}$, it is better to utilize every Pt atom. Therefore, atomic-scale Pt clusters is a promising choice, but it is also a very challenging approach. For instance, Wang et al. [76] fabricated a hybrid catalyst with atomic-scale Pt clusters uniformly decorated on $\alpha-\mathrm{Ni}(\mathrm{OH})_{2}$ nanowires $\left[\mathrm{Pt}_{\mathrm{c}} / \mathrm{Ni}(\mathrm{OH})_{2}\right]$. As a result, its current density normalized to mass specific activity of Pt increased approximately 6.8 times than that of Pt nanoparticles $(d=3 \mathrm{~nm})$ decorated $\mathrm{Ni}(\mathrm{OH})_{2}$ nanowires in alkaline condition.

As valence is directly related to adsorption free energy $\left(\Delta G^{*}\right)$, the lifting of valence always changes the electrocatalytic activity via regulating the $\Delta G^{*}$. For example, $\mathrm{Ni}$ is a relative high active material to HER because of the apposite $\Delta G_{\mathrm{H}} *$. However, when it turned to $\mathrm{Ni}(\mathrm{OH})_{2}$, the $\Delta G_{\mathrm{H}}{ }^{*}$ becomes too positive to act as a HER material $[11,93]$. Moreover, the size can also lift the valence. For instance, when the size of Pt nanoparticles decreased to $2 \mathrm{~nm}$, especially for atomic-scale clusters, the valence of Pt will increase because of the decorated $\mathrm{Ni}(\mathrm{OH})_{2}$ to affect the HER intrinsic activity of Pt-based materials $[40,76,94,95]$. Zhang et al. [73] directly decorated $\mathrm{PtO}_{2}$ on $\mathrm{Ni}(\mathrm{OH})_{2}$ as the HER hybrid materials, which exhibited similar activity to $\mathrm{Pt} / \mathrm{C}$ and durable stability. Furthermore, they replaced $\mathrm{Ni}(\mathrm{OH})_{2}$ by $\mathrm{Co}(\mathrm{OH})_{2}$ and $\mathrm{CoOOH}$. Compared with $\mathrm{Co}(\mathrm{OH})_{2}$, the hybrid materials with $\mathrm{CoOOH}$ exhibited higher active. [15] According to the plentiful literature reports [96-101], however, the $\mathrm{PtO}_{2}$ and $\mathrm{CoOOH}$ should be reduced to Pt and $\mathrm{Co}(\mathrm{OH})_{2}$ easily during process of HER. Therefore, the real valence of materials under potential of HER needs more convincing in-suit characterization.

The other noble metals, such as Ir, Pd and Ru, also exhibit high activity of HER in alkaline media. In fact, there is almost no difference in HER activity between Ir and Pt in acidic media. While in alkaline media, Ir exhibits higher activity than that of Pt with or without decoration of $\mathrm{Ni}(\mathrm{OH})_{2}[81,102]$. Although the HER intrinsic activity of Pd is lower than that of $\mathrm{Pt}$, it will become closer that of $\mathrm{Pt}$ when decorated with $\mathrm{Ni}(\mathrm{OH})_{2}$ $[74,103]$.

\subsubsection{Ni metal and Ni-based alloy}

Among non-noble metal elelctrocatalysts, $\mathrm{Ni}$ has a similar M-H adsorption energy to that of $\mathrm{Pt}$, signifying the relatively high HER activity [104]. Nevertheless, Ni metal does not show enough high electrocatalytic activity in alkaline condition [81]. To optimize the electrochemical activity of HER, alloying and partial oxidation to $\mathrm{NiO}$ or $\mathrm{Ni}(\mathrm{OH})_{2}$ to promote the activity, enlarging specific surface area to increase active area and reducing realistic polarization current density are the effective 
a
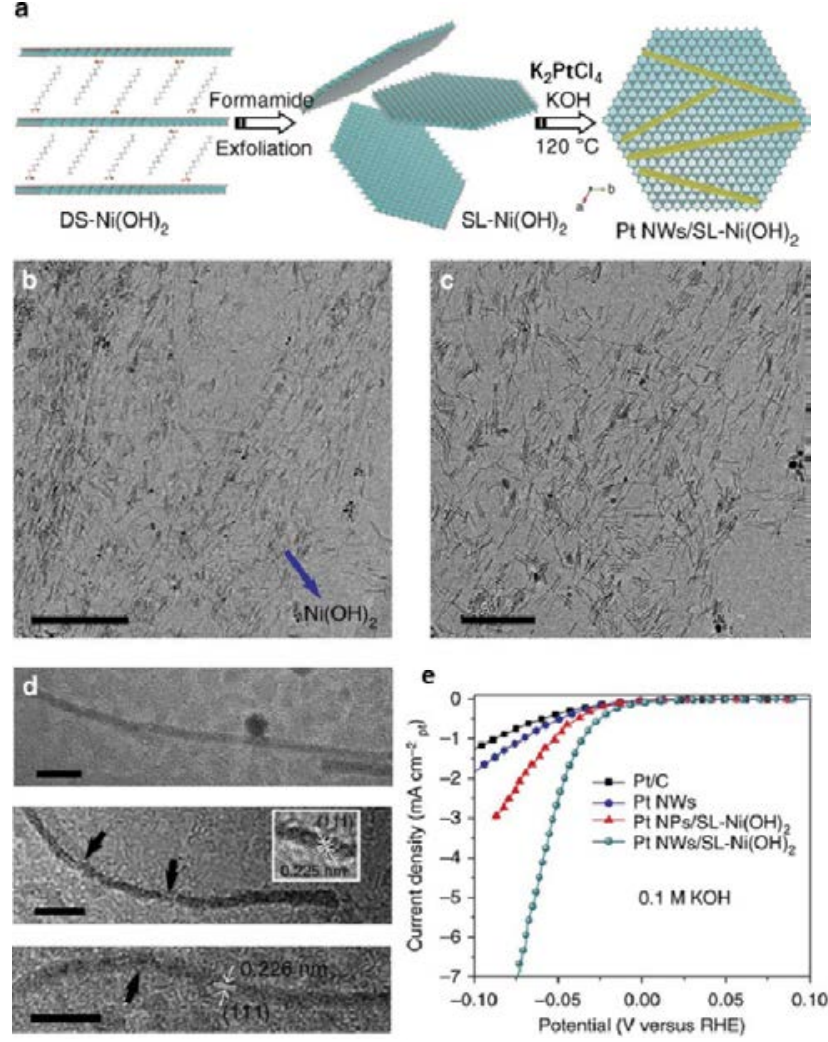

Fig. 5. Schematic illustration of synthesis procedure and the resulting of Pt NWs/SL-Ni(OH)2. (a) Scheme for synthesis of Pt NWs/SL-Ni(OH) (b-d) TEM images of Pt NWs/SL-Ni(OH) 2 with scale bars of 100 (b), 50 (c) and $5 \mathrm{~nm}$ (d); (e) HER activity in $0.1 \mathrm{M} \mathrm{KOH} \mathrm{[40].} \mathrm{Copyright} \mathrm{(2015)}$ Springer Nature.

methods [105-107]. Based on decoration of TM(OH)2, the focus is on alloying and enlarging surface area. Compared with porous $\mathrm{Ni}$, porous $\mathrm{NiCu}$ alloys prepared by electrodeposition exhibit higher activity [108]. Moreover, the activity of the hybrid materials can be improved after being decorated with $\mathrm{Ni}(\mathrm{OH})_{2}$ via cyclic voltammetry (CV) method [109]. Electrodeposition is a method with simple experimental setup as well as easily-controllable synthesis conditions. To compare two typical eletrodeposition methods of potential controlled and current controlled, Ofoli et al. [110] compared CV and constant current (CC) method to deposit Ni films on fluorine-doped tin oxide (FTO)-coated glass. After CV method, the Ni film with a monolayer of firmly packed walnut-shaped particles covered with larger area of $\mathrm{Ni}(\mathrm{OH})_{2}$ exhibited higher HER activity than that of CC method. To further understand the relationship between deposition condition and Ni particles, Kaiser et al. [111] controlled the scan rate and potential range. As a result, the particle size enlarged with the increase of scan rates and the catalytic activity enhanced with the increase of $\mathrm{NiO}$ content. Additionally, the activity of Ni can also be enhanced in acid and neutral conditions when decorated with $\mathrm{Ni}(\mathrm{OH})_{2}$ [112-114]. However, the stability of $\mathrm{Ni}(\mathrm{OH})_{2}$ should be resolved when applied in acid conditions.

\subsubsection{The other non-noble metal-based compounds}

So far, plenty of non-noble metal-based compounds (e.g. $\mathrm{MoS}_{2}, \mathrm{NiS}_{2}, \mathrm{CoP}, \mathrm{Co}_{3} \mathrm{~N}$ and $\mathrm{Mo}_{2} \mathrm{C}$ ) have been developed as cata- lysts for HER with relative high activity $[8,20,24,115,116]$. With decoration of $\mathrm{Ni}(\mathrm{OH})_{2}$, the non-noble metal-based hybrid materials still obey the bi-functional mechanism. $\mathrm{NiS}_{2}$, as the HER catalyst, was widely researched in alkaline conditions. For example, Sun et al. [117] covered electrodeposited amorphous $\mathrm{Ni}(\mathrm{OH})_{2}$ on the surface of $\mathrm{NiS}_{2}$ nanosheet array grown on $\mathrm{Ti}$ mesh, which obviously enhanced the activity of $\mathrm{NiS}_{2}$ [118]. However, the continue increasing HER activity of the $\mathrm{NiS}_{2}$ during HER tests always puzzle the researchers. To explain this phenomenon, Zheng et al. [119] attributed it to the composition change of $\mathrm{NiS}_{2}$ into $\mathrm{Ni}(\mathrm{OH})_{2}$. During HER, the $\mathrm{S}$ in $\mathrm{NiS}_{2}$ was replaced by $\mathrm{OH}$, automatically, the $\mathrm{NiS}_{2}$ was decorated by $\mathrm{Ni}(\mathrm{OH})_{2}$ to enhance the activity by bi-functional mechanism. Moreover, the HER activity of $\mathrm{CoS}_{2}, \mathrm{MoS}_{2}, \mathrm{Ni}_{3} \mathrm{~N}$ and $\mathrm{Fe}_{2} \mathrm{P}$ with surface modification of $\mathrm{Ni}(\mathrm{OH})_{2}$ is proved to be enhanced, especially, the HER performance of $\mathrm{Ni}_{3} \mathrm{~N}$ modified with $\mathrm{Ni}(\mathrm{OH})_{2}$ can be compared to Pt/C [77,78,120,121].

\subsection{LDHs hybrid material}

Layered double hydroxides (LDHs), well-known as efficient electrocatalysts for OER, can effectively adsorb hydroxyl species [115]. However, their HER activity is neglected until Coutanceau's group [122] firstly applied LDH hybrid materials to HER in alkaline condition. In 2013, they found the NiCo alloys, made by microemulsion method, exhibited relatively high HER activity when covered by the "nickel cobalt alloy hydroxides", although they couldn't identify the HER activity of CoNi LDHs immediately. Until to 2017, Bai et al. [123] verified the HER activity of CoNi-LDHs via decorated glass carbon electrode in alkaline condition, which was much higher than that of $\mathrm{Ni}(\mathrm{OH})_{2}$ and $\mathrm{Co}(\mathrm{OH})_{2}$. To further enhance the HER performance of electrode, Lim et al. [124] designed a hierarchical structure of 2D nanosheets-1D nanowires to favor gas bubble de-pinning or wicking of small bubbles to reduce the ohmic drop causing by the adhere bubbles. Although relative high HER activity of NiCo LDHs lack related theoretical supports, according to the electrochemical properties of $\alpha-\mathrm{Ni}(\mathrm{OH})_{2}$ and $\alpha-\mathrm{Co}(\mathrm{OH})_{2}$ which can be reduced to metallic $\mathrm{Ni}$ and Co during $0-50 \mathrm{mV}$ vs. RHE. It is conjectured that the NiCo-LDHs are partly reduced to $\mathrm{Ni}$, Co or the alloy [99,125-128], to form hybrid materials to be explained by the bifunctional mechanism. However, Yang's group [129] found the HER active material of $\mathrm{WCo}(\mathrm{OH})_{x}$ cannot be reduced to metallic $\mathrm{W}$ or Co, which also exhibited high activity both in neutral and alkaline media. They attribute the HER activity of $\mathrm{CoW}(\mathrm{OH})_{\mathrm{x}}$ to the synergy between Co and W, which was similar to the $\mathrm{Ni}(\mathrm{OH})_{2} / \mathrm{Pt}(111)$ system, that the $\mathrm{H}-\mathrm{OH}$ bond was weakened by the interaction of $\mathrm{OH}$ adsorbed on Co atom and $\mathrm{H}$ atom on $\mathrm{W}$ atom as shown in Fig. 6.

Besides of the HER activity, LDHs also retains the properties of effective hydroxide adsorption, indicating it could accelerate water dissociation step of HER in alkaline condition as the same as $\mathrm{TM}(\mathrm{OH})_{2}$. Based on this, Yang's group [130] hybridized vertical $\mathrm{MoS}_{2}$ sheets with NiCo-LDHs, which synergistically favored the adsorption of $\mathrm{H}$ on $\mathrm{MoS}_{2}$ and $\mathrm{OH}$ on $\mathrm{LDH}$ to accelerate the water dissociation via the bi-functional mechanism, as shown in Fig. 7. They also used Tafel analysis to distinguish 


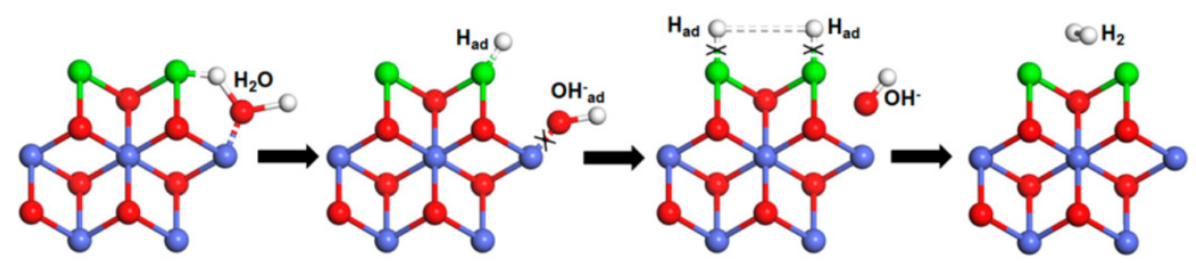

Fig. 6. Schematic illustration of water dissociation, blue, green, red, and white spheres represent Co, W, O, and H atoms, respectively [129]. Copyright (2017) American Chemical Society.

between different mechanistic pathways of $\mathrm{MoS}_{2}$ and $\mathrm{MoS}_{2} / \mathrm{NiCo}-\mathrm{LDH}$. After fitting the linear part to Tafel plot, the Tafel slopes of $\mathrm{MoS}_{2}$ and $\mathrm{MoS}_{2} / \mathrm{NiCo}-\mathrm{LDH}$ catalysts were determined to be 95.7 and $76.6 \mathrm{mV} / \mathrm{dec}$, respectively. The Tafel slopes of the $\mathrm{MoS}_{2}$ and $\mathrm{MoS}_{2} / \mathrm{NiCo}-\mathrm{LDH}$ were within the range of $39-116 \mathrm{mV} / \mathrm{dec}$, indicating that HER was governed by the charge-transfer-induced water dissociation process, for which the Volmer step and Heyrovsky step became kinetically comparable. And the significantly lower Tafel slope value of $\mathrm{MoS}_{2} / \mathrm{NiCo}-\mathrm{LDH}$ composite than that of $\mathrm{MoS}_{2}$ indicated a superior HER kinetics. Additionally, Gao et al. [131] found that the decorated NiCo-LDH can promote the intrinsic activity of $\mathrm{CoNiSe}_{2}$. To further enhance the performance of NiCo-LDH, Zhao et al. [132] doped $\mathrm{Cu}(0)$ to fabricate $\mathrm{Cu}(0)-\mathrm{CoNi}-\mathrm{OH}$ grown on NF. Due to the unique metal/hydroxide interfaces and increased ECSA after $\mathrm{Cu}$ doping, the fabricated electrode exhibited high performance that only requires an overpotential of $47 \mathrm{mV}$ to reach $10 \mathrm{~mA} \mathrm{~cm}^{-2}$.

\section{Overall water splitting}

Recently, earth-abundant transition metal-based compounds have been extensively pursued as promising inexpensive alternatives of noble metal catalysts for HER and OER [138-140]. However, it is still difficult to couple the HER and OER electrocatalysts in a single electrolyzer for water electrolysis. Due to the mismatch between the optimal electrolytes for the reactions in the two directions that OER catalysts perform better under alkaline conditions, whereas HER catalysts prefer acidic media [16,141,142]. Meanwhile, the use of electrodes that are made from two different materials for individual HER and OER reactions would inevitably introduce cost concerns and manufacturing complexities [143]. Hence, it is seriously urgent to design bi-functional electrocatalysts or electrodes with efficient performance to both the HER and OER under the same conditions [144]. The core reactions of the electrocatalytic HER and OER, which involve breakage of $\mathrm{O}-\mathrm{H}$ bonds and formation of 0-0 double bonds accompanied by the release of
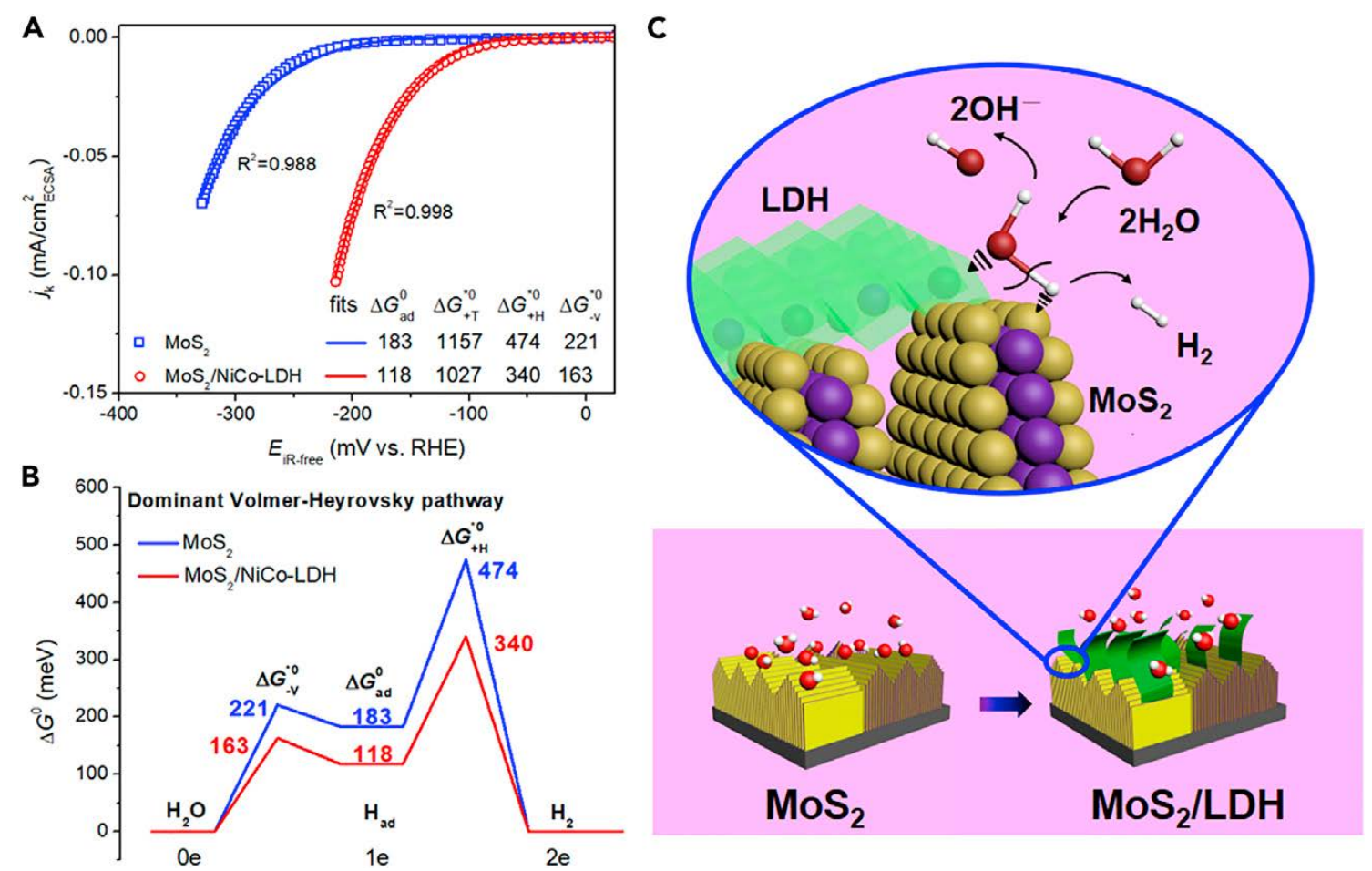

Fig. 7. HER kinetics analysis of the $\mathrm{MoS}_{2} / \mathrm{NiCo}-\mathrm{LDH}$ composite. (A) ECSA normalized polarization curves (symbols) with the best fits (lines) using the dual-pathway kinetic model. (B) Free energy diagram of the dominant Volmer-Heyrovsky pathway for HER in alkaline electrolyte. (C) Schematic illustration of the HER in $\mathrm{MoS}_{2} / \mathrm{LDH}$ interface in alkaline environment [130]. Copyright (2017) Elsevier. 
protons and electrons, are unfortunately kinetically sluggish [90]. However, profiting from the synergistic effect or bi-functional mechanism from $\mathrm{TM}(\mathrm{OH})_{x}$, the HER performance of the corresponding electrode is promoted obviously in alkaline condition as described before. Moreover, the $\mathrm{TM}(\mathrm{OH})_{x}$ also exhibits high OER activity, such as NiFe-LDHs [138]. Therefore, the bifunctional electrocatalysts/electrodes of HER and OER have been widely investigated $[13,38,90]$, some of typical samples are summarized in Table 2. Following, the bifunctional electrocatalysts/electrodes will be concluded on the focus of HER, involving with electrochemical activity, mass transfer, conductivity and stability.

\subsection{Electrochemical activity}

\subsubsection{Intrinsic activity}

Intrinsic activity of HER and OER depends highly on the species of the using catalysts, which can be affected or modified by composition, doping and defect. These changes determine or regulate the materials' electronic structure, an important descriptor to explain the catalytic behavior, via altering the conductivity and adsorption strength of the intermediates to directly determine the reaction kinetics [145-147].

4.1.1.1. Species

Markovic's group [80] investigated the trends in activity for HER and OER on TM hydr(oxy)oxides in alkaline condition. They found the HER activity was mainly depended on the substrates (Pt, Ni and $\mathrm{Au}$ ) while affected by the different modified $\mathrm{TM}(\mathrm{OH})_{x}$. However, the OER activity was only depend on the species of $\mathrm{TMO}(\mathrm{OH})_{\mathrm{x}}$ with trend of $\mathrm{Mn}<\mathrm{Fe}<\mathrm{Co}<\mathrm{Ni}$. It indi-

Table 2

Summary of recent reported bifunctional TM(OH) $)_{x}$ hybrid materials for HER and OER.

\begin{tabular}{|c|c|c|c|c|c|}
\hline Material & Method & Overpotential of HER & Overpotential of OER & Electrolyte & Ref. \\
\hline $\mathrm{Ni}(\mathrm{OH})_{2} / \mathrm{NF}$ & Hydrothermal & $303 \mathrm{mV}$ at $100 \mathrm{~mA} \mathrm{~cm}^{-2}$ & $400 \mathrm{mV}$ at $100 \mathrm{~mA} \mathrm{~cm}^{-2}$ & $1 \mathrm{M} \mathrm{KOH}$ & [144] \\
\hline $\mathrm{Ni}(\mathrm{OH})_{2} / \mathrm{NiAl}$ & Alkali-etching & $292 \mathrm{mV}$ at $10 \mathrm{~mA} \mathrm{~cm}^{-2}$ & $289 \mathrm{mV}$ at $10 \mathrm{~mA} \mathrm{~cm}^{-2}$ & $1 \mathrm{M} \mathrm{KOH}$ & [168] \\
\hline $\mathrm{Co}(\mathrm{OH})_{2} / \mathrm{NF}$ & Hydrothermal & $260 \mathrm{mV}$ at $10 \mathrm{~mA} \mathrm{~cm}^{-2}$ & $270 \mathrm{mV}$ at $10 \mathrm{~mA} \mathrm{~cm}^{-2}$ & $1 \mathrm{M} \mathrm{KOH}$ & [157] \\
\hline $\mathrm{CoPt}-\mathrm{Co}(\mathrm{OH})_{2}$ & Deposition & $226 \mathrm{mV}$ at $50 \mathrm{~mA} \mathrm{~cm}^{-2}$ & $334 \mathrm{mV}$ at $10 \mathrm{~mA} \mathrm{~cm}^{-2}$ & $1 \mathrm{M} \mathrm{KOH}$ & [191] \\
\hline $\mathrm{Au}-\mathrm{Co}(\mathrm{OH})_{2}$ & Electrodeposition & $424 \mathrm{mV}$ at $10 \mathrm{~mA} \mathrm{~cm}^{-2}$ & $390 \mathrm{mV}$ at $10 \mathrm{~mA} \mathrm{~cm}^{-2}$ & $0.1 \mathrm{M} \mathrm{KOH}$ & [195] \\
\hline $\mathrm{Co}(\mathrm{OH})_{2}-\mathrm{Au}-\mathrm{Ni}(\mathrm{OH})_{2}$ & Electrodeposition & $200 \mathrm{mV}$ at $10 \mathrm{~mA} \mathrm{~cm}^{-2}$ & $340 \mathrm{mV}$ at $10 \mathrm{~mA} \mathrm{~cm}^{-2}$ & $1 \mathrm{M} \mathrm{NaOH}$ & {$[171]$} \\
\hline NiFe HNSs & & $189 \mathrm{mV}$ & $220 \mathrm{mV}$ & & \\
\hline NiCo HNSs & & $230 \mathrm{mV}$ & $282 \mathrm{mV}$ & & \\
\hline NiMn HNSs & Hydrotr & $302 \mathrm{mV}$ & $312 \mathrm{mV}$ & I M КUН & [149] \\
\hline $\mathrm{Ni}(\mathrm{OH})_{2} \mathrm{NSs}$ & & $374 \mathrm{mV}$ at $10 \mathrm{~mA} \mathrm{~cm}^{-2}$ & $350 \mathrm{mV}$ at $10 \mathrm{~mA} \mathrm{~cm}^{-2}$ & & \\
\hline $\mathrm{CoFe}-\mathrm{OH} / \mathrm{NF}$ & Electrodeposition & $110 \mathrm{mV}$ at $10 \mathrm{~mA} \mathrm{~cm}^{-2}$ & $220 \mathrm{mV}$ at $10 \mathrm{~mA} \mathrm{~cm}^{-2}$ & $1 \mathrm{M} \mathrm{KOH}$ & [158] \\
\hline NiCo-LDH/NF & Hydrothermal & $162 \mathrm{mV}$ at $10 \mathrm{~mA} \mathrm{~cm}^{-2}$ & $271 \mathrm{mV}$ at $10 \mathrm{~mA} \mathrm{~cm}^{-2}$ & $1 \mathrm{M} \mathrm{KOH}$ & {$[170]$} \\
\hline $\mathrm{Ni}_{5} \mathrm{Fe}-\mathrm{LDH} / \mathrm{NF}$ & & $133 \mathrm{mV}$ & $210 \mathrm{mV}$ & & \\
\hline $\mathrm{Ni}_{5} \mathrm{Co}-\mathrm{LDH} / \mathrm{NF}$ & Hydrothermal & $178 \mathrm{mV}$ at $10 \mathrm{~mA} \mathrm{~cm}^{-2}$ & $298 \mathrm{mV}$ at $10 \mathrm{~mA} \mathrm{~cm}^{-2}$ & $1 \mathrm{M} \mathrm{KOH}$ & [196] \\
\hline $\mathrm{Ni}_{0.75} \mathrm{Fe}_{0.25}-\mathrm{LDH} / \mathrm{NF}$ & Hydrothermal & $169 \mathrm{mV}$ at $10 \mathrm{~mA} \mathrm{~cm}^{-2}$ & $239 \mathrm{mV}$ at $50 \mathrm{~mA} \mathrm{~cm}^{-2}$ & $1 \mathrm{M} \mathrm{NaOH}$ & {$[154]$} \\
\hline CoFe-LDH/NF & Deposition & $166 \mathrm{mV}$ at $10 \mathrm{~mA} \mathrm{~cm}^{-2}$ & $260 \mathrm{mV}$ at $10 \mathrm{~mA} \mathrm{~cm}^{-2}$ & $1 \mathrm{M} \mathrm{KOH}$ & [164] \\
\hline $\mathrm{Ni}_{5} \mathrm{Co}_{3} \mathrm{Mo}-\mathrm{OH} / \mathrm{NF}$ & Corroding & $52 \mathrm{mV}$ at $10 \mathrm{~mA} \mathrm{~cm}^{-2}$ & $304 \mathrm{mV}$ at $100 \mathrm{~mA} \mathrm{~cm}^{-2}$ & $1 \mathrm{M} \mathrm{KOH}$ & [182] \\
\hline NiFeCo-LDH/NF & Electrodeposition & $108 \mathrm{mV}$ at $10 \mathrm{~mA} \mathrm{~cm}^{-2}$ & $210 \mathrm{mV}$ at $10 \mathrm{~mA} \mathrm{~cm}^{-2}$ & $1 \mathrm{M} \mathrm{KOH}$ & [197] \\
\hline $\mathrm{CoMnCH} / \mathrm{NF}$ & & $328 \mathrm{mV}$ & $387 \mathrm{mV}$ & & \\
\hline $\mathrm{CoCH}$ & Hydrothermal & $356 \mathrm{mV}$ at $100 \mathrm{~mA} \mathrm{~cm}^{-2}$ & $349 \mathrm{mV}$ at $100 \mathrm{~mA} \mathrm{~cm}^{-2}$ & $1 \mathrm{M} \mathrm{КОН}$ & [162] \\
\hline $\mathrm{Se}-(\mathrm{NiCo}) \mathrm{S} / \mathrm{OH} / \mathrm{NF}$ & & $101 \mathrm{mV}$ & $155 \mathrm{mV}$ & & \\
\hline (NiCo)S/OH/NF & Hydrothermal & $171 \mathrm{mV}$ & $227 \mathrm{mV}$ & $1 \mathrm{M} \mathrm{KOH}$ & [165] \\
\hline (NiCo)OH/NF & & $207 \mathrm{mV}$ at $10 \mathrm{~mA} \mathrm{~cm}^{-2}$ & $238 \mathrm{mV}$ at $10 \mathrm{~mA} \mathrm{~cm}^{-2}$ & & \\
\hline NiCoFe-LTH/CC & Electrodeposition & $200 \mathrm{mV}$ at $10 \mathrm{~mA} \mathrm{~cm}^{-2}$ & $230 \mathrm{mV}$ at $10 \mathrm{~mA} \mathrm{~cm}^{-2}$ & $1 \mathrm{M} \mathrm{KOH}$ & [155] \\
\hline NiFeV-LDH/NF & Hydrothermal & $125 \mathrm{mV}$ at $10 \mathrm{~mA} \mathrm{~cm}^{-2}$ & $231 \mathrm{mV}$ at $10 \mathrm{~mA} \mathrm{~cm}^{-2}$ & $1 \mathrm{M} \mathrm{KOH}$ & [153] \\
\hline NiCoFe-LDH/NF & Electrodeposition & $200 \mathrm{mV}$ at $40 \mathrm{~mA} \mathrm{~cm}^{-2}$ & $275 \mathrm{mV}$ at $10 \mathrm{~mA} \mathrm{~cm}^{-2}$ & $0.1 \mathrm{M} \mathrm{KOH}$ & [189] \\
\hline NiFe LDH-DG & & $210 \mathrm{mV}$ & $300 \mathrm{mV}$ & & \\
\hline NiFe LDH-NG & Hetero assembled & $\sim 230 \mathrm{mV}$ & $360 \mathrm{mV}$ & $1 \mathrm{M} \mathrm{KOH}$ & {$[166]$} \\
\hline NiFe LDH-G & & $\sim 240 \mathrm{mV}$ at $10 \mathrm{~mA} \mathrm{~cm}^{-2}$ & $440 \mathrm{mV}$ at $10 \mathrm{~mA} \mathrm{~cm}^{-2}$ & & \\
\hline $\mathrm{Ni}_{2} \mathrm{P}-\mathrm{NiFe}-\mathrm{OH} / \mathrm{NF}$ & Hydrothermal & $75 \mathrm{mV}$ at $10 \mathrm{~mA} \mathrm{~cm}^{-2}$ & $205 \mathrm{mV}$ at $10 \mathrm{~mA} \mathrm{~cm}^{-2}$ & $1 \mathrm{M} \mathrm{KOH}$ & [192] \\
\hline $\mathrm{Ni}(\mathrm{OH})_{2}-\mathrm{Ni} / \mathrm{CC}$ & Electrodeposition & $68 \mathrm{mV}$ at $10 \mathrm{~mA} \mathrm{~cm}^{-2}$ & $458 \mathrm{mV}$ at $100 \mathrm{~mA} \mathrm{~cm}-2$ & $1 \mathrm{M} \mathrm{KOH}$ & {$[71]$} \\
\hline NiFe LDH-Cu NWs/NF & Electrodeposition & $116 \mathrm{mV}$ at $10 \mathrm{~mA} \mathrm{~cm}^{-2}$ & $199 \mathrm{mV}$ at $10 \mathrm{~mA} \mathrm{~cm}^{-2}$ & $1 \mathrm{M} \mathrm{KOH}$ & [167] \\
\hline $\mathrm{Ni} / \mathrm{NiFe}-\mathrm{OH} / \mathrm{NF}$ & Electrodeposition & $154 \mathrm{mV}$ at $10 \mathrm{~mA} \mathrm{~cm}^{-2}$ & $205 \mathrm{mV}$ at $10 \mathrm{~mA} \mathrm{~cm}^{-2}$ & $1 \mathrm{M} \mathrm{KOH}$ & [143] \\
\hline NiFe LDH-NiSe /NF & Hydrothermal & $276 \mathrm{mV}$ at $100 \mathrm{~mA} \mathrm{~cm}^{-2}$ & $240 \mathrm{mV}$ at $100 \mathrm{~mA} \mathrm{~cm}^{-2}$ & $1 \mathrm{M} \mathrm{KOH}$ & [177] \\
\hline $\mathrm{NiCo}_{2} \mathrm{~S}_{4}-\mathrm{NiFe} \mathrm{LDH} / \mathrm{NF}$ & Hydrothermal & $200 \mathrm{mV}$ at $10 \mathrm{~mA} \mathrm{~cm}^{-2}$ & $201 \mathrm{mV}$ at $60 \mathrm{~mA} \mathrm{~cm}^{-2}$ & $1 \mathrm{M} \mathrm{KOH}$ & {$[150]$} \\
\hline $\mathrm{CoNiSe}_{2} @ \mathrm{CoNi}-\mathrm{LDHs} / \mathrm{NF}$ & Hydrothermal \& electrodeposition & $106 \mathrm{mV}$ at $10 \mathrm{~mA} \mathrm{~cm}^{-2}$ & $208 \mathrm{mV}$ at $10 \mathrm{~mA} \mathrm{~cm}^{-2}$ & $1 \mathrm{M} \mathrm{KOH}$ & [131] \\
\hline $\mathrm{NiFe}-\mathrm{LDH} / \mathrm{NiCo}_{2} \mathrm{O}_{4} / \mathrm{NF}$ & Hydrothermal & $192 \mathrm{mV}$ at $10 \mathrm{~mA} \mathrm{~cm}^{-2}$ & $290 \mathrm{mV}$ at $50 \mathrm{~mA} \mathrm{~cm}^{-2}$ & $1 \mathrm{M} \mathrm{KOH}$ & [151] \\
\hline $\mathrm{CoS}-\mathrm{Co}(\mathrm{OH})_{2} / \mathrm{MoS}_{\mathrm{x}} / \mathrm{NF}$ & Den & $143 \mathrm{mV}$ & $380 \mathrm{mV}$ & $1 \mathrm{M}$ & {$[1$} \\
\hline $\mathrm{NiS}-\mathrm{Ni}(\mathrm{OH})_{2} / \mathrm{MoS}_{\mathrm{x}} / \mathrm{NF}$ & Depo & $226 \mathrm{mV}$ at $10 \mathrm{~mA} \mathrm{~cm}^{-2}$ & $417 \mathrm{mV}$ at $10 \mathrm{~mA} \mathrm{~cm}^{-2}$ & I IM KUH & {$[1$} \\
\hline$(\mathrm{Ni}-\mathrm{Fe}) \mathrm{S}_{\mathrm{x}} / \mathrm{NiFe}(\mathrm{OH})_{\mathrm{y}}$ & Electrodeposition & $124 \mathrm{mV}$ at $100 \mathrm{~mA} \mathrm{~cm}^{-2}$ & $290 \mathrm{mV}$ at $100 \mathrm{~mA} \mathrm{~cm}^{-2}$ & $1 \mathrm{M} \mathrm{KOH}$ & [180] \\
\hline Pt-NiFe-LDH/CC & Hydrothermal & $101 \mathrm{mV}$ at $10 \mathrm{~mA} \mathrm{~cm}^{-2}$ & $230 \mathrm{mV}$ at $10 \mathrm{~mA} \mathrm{~cm}^{-2}$ & $1 \mathrm{M} \mathrm{KOH}$ & [190] \\
\hline NiFeRu-LDH/NF & Hydrothermal & $29 \mathrm{mV}$ at $10 \mathrm{~mA} \mathrm{~cm}^{-2}$ & $225 \mathrm{mV}$ at $10 \mathrm{~mA} \mathrm{~cm}^{-2}$ & $1 \mathrm{M} \mathrm{NaOH}$ & [135] \\
\hline AuNPs-CaFe-LDH & Co-precipitation & $\sim 500 \mathrm{mV}$ at $27 \mathrm{~mA} \mathrm{~cm}^{-2}$ & $510 \mathrm{mV}$ at $10 \mathrm{~mA} \mathrm{~cm}^{-2}$ & $1 \mathrm{M} \mathrm{KOH}$ & [176] \\
\hline AuNDs-CaFeMg-LDH & Deposition & $\sim 550 \mathrm{mV}$ at $19 \mathrm{~mA} \mathrm{~cm}^{-2}$ & $\sim 570 \mathrm{mV}$ at $13 \mathrm{~mA} \mathrm{~cm}^{-2}$ & $1 \mathrm{M} \mathrm{KOH}$ & {$[174]$} \\
\hline
\end{tabular}




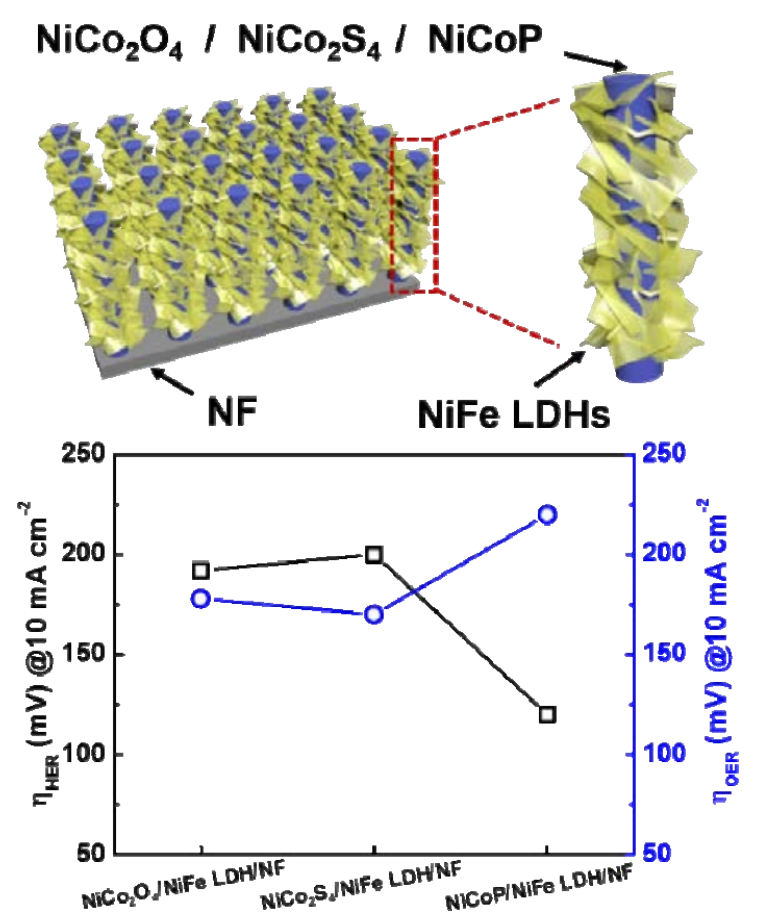

Fig. 8. Schematic illustration of $\mathrm{NiCo}_{2} \mathrm{O}_{4} / \mathrm{NiFe} \mathrm{LDH} / \mathrm{NF}, \mathrm{NiCo}_{2} \mathrm{~S}_{4} / \mathrm{NiFe}$ $\mathrm{LDH} / \mathrm{NF}$ or $\mathrm{NiCoP} / \mathrm{NiFe} \mathrm{LDH} / \mathrm{NF}$ electrodes and the corresponding electrochemical performance of HER and OER in $1 \mathrm{M} \mathrm{KOH}$.

cates the substrates supply HER a ctive sites, while modified $\mathrm{TMO}(\mathrm{OH})_{\mathrm{x}}$ supply OER active sites. In acidic and neutral conditions, Lim et al. [148] enriched the HER and OER activity trends of TMO $(\mathrm{OH})_{\mathrm{x}}$ using of inactive $\mathrm{GC}$ as the substrate, consisting with the conclusion of Markovic's group. When the substrate was changed to NF, the hybrid electrodes performed much better than that of GC. For instance, based on NF substrate,
Huang's group [149] compared the activity of NiFe, NiCo and NiMn hydroxide nanosheets (HNSs) for HER and OER, they found the NiFe HNSs exists the best performance. Wang, Liu and Zhang et al. [150-152] respectively designed the $\mathrm{Ni}$ $\mathrm{Co}_{2} \mathrm{O}_{4} / \mathrm{NiFe} \mathrm{LDH} / \mathrm{NF}, \mathrm{NiCo}_{2} \mathrm{~S}_{4} / \mathrm{NiFe} \mathrm{LDH} / \mathrm{NF}$ and $\mathrm{NiCoP} / \mathrm{NiFe}$ LDH/NF electrodes with similar structure as shown in Fig. 8. Benefiting to the structure of nanowire arrays and the decorated $\mathrm{NiFe} \mathrm{LDH}$, these electrodes exhibited low overpotential of OER. To enhance the HER performance, the nanowires were exchanged from $\mathrm{NiCo}_{2} \mathrm{O}_{4}$ to $\mathrm{NiCo}_{2} \mathrm{~S}_{4}$ and $\mathrm{NiCoP}$. As a result, the $\mathrm{NiCoP} / \mathrm{NiFe} \mathrm{LDH} / \mathrm{NF}$ electrode displayed a better HER performance because of the higher intrinsic activity.

\subsubsection{Composition}

The electrochemical activity of $\mathrm{TM}(\mathrm{OH})_{x}$ for HER and OER depends strongly on TM/TM composition. For instance, Yan's group [153] found that NiFeV-LDHs/NF with different ratio of $\mathrm{Ni}, \mathrm{Fe}$ and $\mathrm{V}$ not only boosted the surface area, but also increased the intrinsic activity that the only double ECSA leads to over eight times current density improvement. To deeply understand the change of activity via altering the ratio of $\mathrm{Fe} / \mathrm{Ni}$, Liu et al. [154] changed the content of Fe in NiFe LDHs grown on $\mathrm{NF}$, which exhibited relatively high activity under $\mathrm{Ni}-\mathrm{Fe}$ ratio of 3:1. However, the HER performance contradicted to the trends of Markovic's result, which may cause by the enlarged surface area. Additionally, Co is always doped to enhance the catalytic activity of HER and OER because of its proper $3 d$ electronic orbit [155-158]. For instance, Pan's group [159] investigated the HER and OER performance of a series of Co- and Fe-doped Ni-based hydroxide catalysts in detail. As shown in Fig. 9, the HER performance is enhanced by Co doping, while deteriorated by Fe doping. For OER, both of Co and Fe doping promotes the activity. The mechanism of higher activity caused by Co doping may be described that the Co pushes its partial electrons to $\mathrm{Ni}$ site to promote the charge transfer process from $\mathrm{Ni}$ site to the adsorbed $\mathrm{H}_{2} \mathrm{O}$, which prompts to increase the
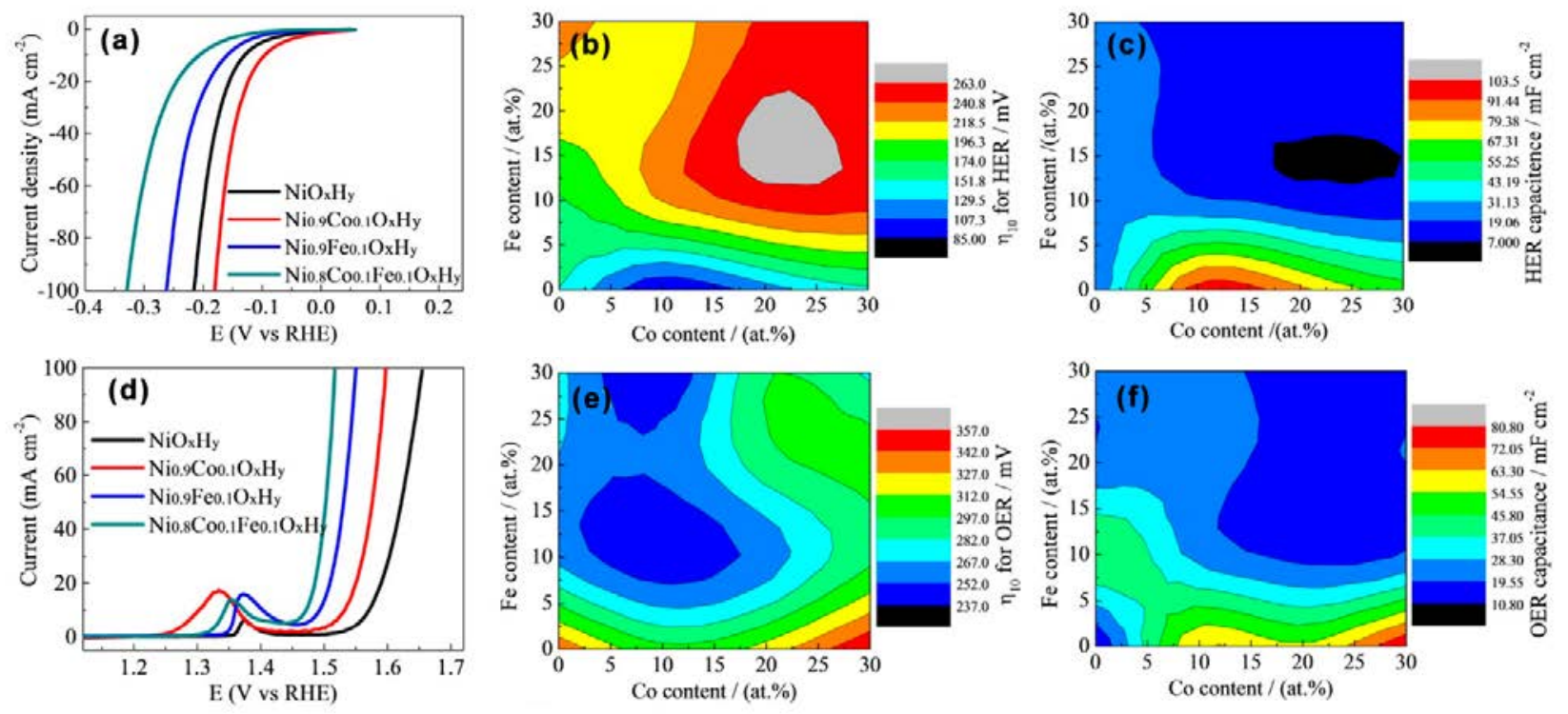

Fig. 9. HER and OER performance of the Ni-based hydroxides. HER (a) and OER (d) curves and overpotentials $(\eta)$ at $10 \mathrm{~mA} \mathrm{~cm}^{-2}$ (b, e), electric double layer capacitance (c, f) of the Ni-based hydroxides vs Co and Fe fractions [159]. Copyright (2018) American Chemical Society. 
number of lattice $\mathrm{O}^{2-}$ as HER active sites.

\subsubsection{Doping}

Doping is an effective method to change the intrinsic activity of electrocatalysts via the electronic modulation [160,161], including heteroatom doping and vacancy doping. For heteroatom doping, $\mathrm{Hu}$ and co-workers [162] found that Mn doping can appreciably modulate the electronic structure of Co centers via down-shifting of $0.7 \mathrm{eV}$ to enhance the activity of Co carbonate hydroxide ( $\mathrm{CoCH})$. Benefited from increased ECSA and intrinsic activity of $\mathrm{MnCoCH}$ due to the dual modulation of Mn doping, it performed a stable overall water splitting with a cell voltage of $1.68 \mathrm{~V}$ at $10 \mathrm{~mA} \mathrm{~cm}-2$. As to vacancy doping, Kim's group [163] designed a binder-free CoS-doped $\beta-\mathrm{Co}(\mathrm{OH})_{2} / \mathrm{MoS}_{2+\mathrm{x}} / \mathrm{NF}$ electrode with abundance of S vacancy for HER and OER. As a result, the enhanced HER activity was mainly attributed to $S$ vacancy doping (unsaturated $S$ ), while CoS-doped $\beta$ - $\mathrm{Co}(\mathrm{OH})_{2}$ played a major role in OER. Besides electronic modulation, doping is also a method to enhance the conductivity and surface area, which would be discussed in the next Sections of 4.1.2 and 4.2.

\subsubsection{Defect}

Defects can subtly tune the adsorption of reaction intermediates to enhance the activity, including unsaturation, disorders and holes here. For unsaturation, Liu et al. [164] created coordinative unsaturated metals of ultra-thin CoFe LDH via delamination and exfoliation in DMF-ethanol solvent. In $1 \mathrm{M} \mathrm{KOH}$, the CoFe LDH approached the performance of Pt for HER and outperformed $\mathrm{IrO}_{2}$ electrocatalyst in activity and stability for OER. About disorders, Hu et al. [165] constructed ultrathin disorder-rich Se-(NiCo)S $\mathrm{S}_{x} /(\mathrm{OH})_{x}$ nanosheets via a facile Se-induced treatment, attributed to the structure transfer and phase separation. The defects and disorder of the $\mathrm{Se}-(\mathrm{NiCo}) \mathrm{S} / \mathrm{OH}$ were more favorable for adsorbing $\mathrm{OH}^{-}$. Hence, Se-(NiCo)S/OH exhibited better OER activity than ( $\mathrm{NiCo}) \mathrm{S} / \mathrm{OH}$ and $(\mathrm{NiCo}) \mathrm{OH}$ to lower the overpotential for water splitting. Moreover, defects of holes can provide anchor sites via high surface free energy or other interactions to couple active materials and substrate, leading to excellent stability and fast electron transfer. For instance, Yao's group [166] demonstrated a heterostructured NiFe LDH-NS@DG10 hybrid catalyst by coupling of exfoliated NiFe-LDH nanosheet (NS) and defective graphene (DG). They suggested that the localized electrons accumulation at the defect sites was supposed to enhance the HER, while the electron transfer in the hole accumulation on NiFe LDH-NS is favored to OER. Thus, the high defect density of the defective graphene coupled with NiFe LDH-NS supplies more active site to higher activity of HER/OER.

\subsubsection{Active area}

The more active sites provide higher reaction probability for electrochemical reaction to increase the catalytic activity on specific electrode area. Enlarging the specific area is a direct method to increase the number of active sites, such as rougher substrate [167] and smaller size of active materials [164]. For instance, to increase the specific area of NiMo alloy, Niu et al. [168] roughened the NiAl substrate by the grown $\mathrm{Ni}(\mathrm{OH})_{2}$ before electrodeposition of NiMo nanoparticles, which lowered the overpotential for water splitting. Additionally, morphology control [169,170], doping [158] and defect [165] are the more effective methods to not only increase the number but also enhance the ratio of the active sites. For morphology control, NiCo LDH nanosheets exhibit higher activity for both HER and OER than that of NiCo LDH powders. Compared with $\mathrm{NiCo}_{2} \mathrm{O}_{4}$ nanosheets, the $\mathrm{NiCo}_{2} \mathrm{O}_{4}$ nanowires are prefer for OER, but not for HER. For doping, Sultana et al. [171] doped gold on a layer of electrodeposited $\mathrm{Co}(\mathrm{OH})_{2}$ prior to electrodepositing $\mathrm{Ni}(\mathrm{OH})_{2}$ via galvanic replacement method. With the help of gold doping, the corresponding electrode displayed excellent activity for both HER and OER. To increase the defects, Zhang's group [172] used a simple OER activation method to fabricate oxygen deficiencies-rich Ni/NiOOH hybrid film, which obviously enhanced the activity of HER and OER.

\subsubsection{Synergistic effect}

Synergistic effects, a special emphasis between the two components, result in an enhanced performance compared with each single component. [173] The mechanism of synergistic effect has been described clearly in Section 3.1 (the bi-functional mechanism), including interaction between metal and $\mathrm{TM}(\mathrm{OH})_{x}$ [174-176], compounds and $\mathrm{TM}(\mathrm{OH})_{x}$ [177], ions and ions [60,155,178]. For example, Edvinsson's group [179] suggested that the synergistic effect between $\mathrm{Fe}$ and $\mathrm{Ni}$ in $\mathrm{NiFe}$ LDHs for overall water splitting as shown in Fig. 10. For HER on NiFe LDH, water molecular dissociatively adsorbs on the metal center, forming $\mathrm{H}_{\mathrm{ad}}$ on the $\mathrm{Ni}$ center $\left(\mathrm{H}_{\mathrm{ad}}-\mathrm{NiO}\right)$, as well as forming $\mathrm{OH}_{\mathrm{ad}}$ on the $\mathrm{Fe}$ center $\left(\mathrm{OH}_{\mathrm{ad}}-\mathrm{FeO}\right)$, subsequently releasing $\mathrm{OH}^{-}$when accepting the electron. Then hydrogen from the second $\mathrm{H}_{2} \mathrm{O}$ associates with the $\mathrm{H}_{\mathrm{ad}}-\mathrm{NiO}$ group to form $\mathrm{H}_{2}$. For $\mathrm{OER}, \mathrm{OH}^{-}$from the aqueous electrolyte is found to adsorb on the $\mathrm{Ni}$ center (the active $\mathrm{Ni}$ phase in $\mathrm{NiOOH}$-mediated OER is the high Ni valency-containing $\gamma$-NiOOH induced by $\mathrm{Fe}^{3+}$ ) at modest overpotentials $(\eta \sim 200-300 \mathrm{mV})$, forming $\mathrm{OH}_{\mathrm{ad}}$ intermediate on the Ni site. The $\mathrm{OH}_{\text {ad }}$ react with other $\mathrm{OH}_{a d}$ to form reaction intermediates that are further oxidized to $\mathrm{O}_{2}$ and $\mathrm{H}_{2} \mathrm{O}$. To promote the synergistic effect, which is always associated with high specific area with maximized interaction area/length and multicomponent interaction, such as the micro/nano hierarchical architectures to enlarge the interaction area [180] and three components coupling of $\mathrm{rGO}_{2} \mathrm{MoS}_{2}$ and $\mathrm{Ni}(\mathrm{OH})_{2}$ [181]. Another way is to enhance the intrinsic synergistic effect via

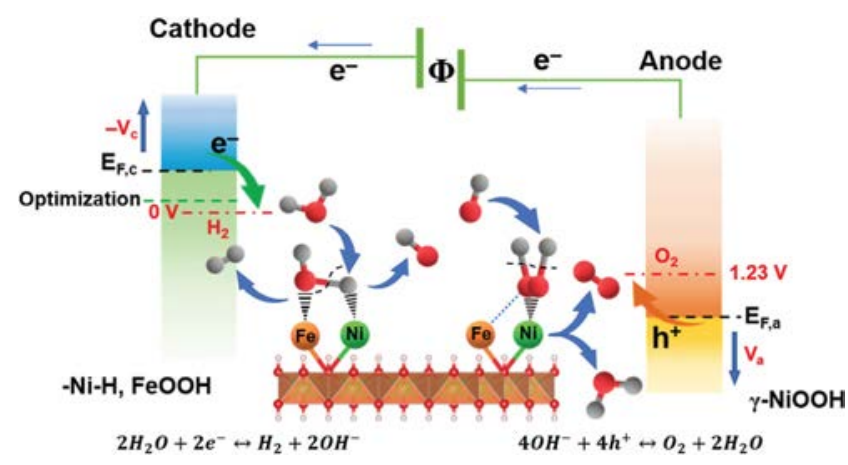

Fig. 10. Schematic representation of the electrocatalytic water splitting in alkaline media [179]. Copyright (2019) The Royal Society of Chemistry. 
optimizing the electronic structure. For instance, the $\mathrm{Ir}^{4+}$-doped $\mathrm{NiFe} \mathrm{LDH}$ accelerates the water dissociation process to enhance the HER performance, while it makes little contribution to OER [178]. Therefore, synergistic effect is always a complicated comprehensive effect to enhance the electrocatalytic performance [182-184].

\subsection{Mass transfer}

Compared with enhancing of electrochemical activity, the research for mass transfer is relatively less. However, an excellent performance electrode must take mass transfer into account, especially for high current density and engineering application. In alkaline condition, the main HER researches for mass transfer polarization are focus on driving off the electrode-attached gas bubbles [185]. Although inducing ultragravity or ultrasonic treatment is beneficial to the disengagement of gas bubbles, they are not cost-effective for industrial production [186]. Therefore, it is better to design a nanoporous hydrophilic surface structure to rapid remove the surface attached gas bubbles. In detail, the nanoporous architecture of electrode surface can transform the three phase contact line of gas bubbles with the solid electrode into a discontinuous state, resulting in extremely low adhesive force between them and excellent bubble departure ability, thus promoting the electrocatalytic performance [144]. For instance, Tang et al. [187] designed an effective gas escaping electrode with structure of vertical $\mathrm{NiCo}(\mathrm{OH})_{x}$ nanosheets assembled on graphene surface, which exhibited a smaller contact angle of $\approx 0^{\circ}$ than the original nickel foam with a contact angle of $\approx 90^{\circ}$ and good performance for water splitting [180]. In addition, a good hydrophilic surface is benefit to release the gas bubbles via enlarging the contact angle of bubbles on the electrode surface to decrease the adsorption force and area. For example, Sun et al. [105] synthesize the ultrathin nickel nanosheet arrays (Ni-NSAs) on nickel foam as the HER electrode. Benefiting to the superaerophobic arrayed structure, the partial oxidization of Ni-NSAs resulted in effective water-splitting electrocatalysts for HER.

\subsection{Conductivity}

Enhancing the conductivity of electrode materials is unavoidable to lower the ohmic resistance, especially for high current density of water splitting. The electrode conductivity involves that the electron transfers from substrate to OER active sites, or in reverse, from HER active sites to substrate. These require high conductivity between substrate and active sites. For HER electrode based on $\mathrm{TM}(\mathrm{OH})_{x}$, the active sites are surrounded with the interface of HER active materials and $\mathrm{TM}(\mathrm{OH})_{x}$. To enhance the conductivity of the electrode, it's better for the high-conductivity active materials to close enough to substrate. However, as for OER electrode, the TM(OH) $)_{x}$ provides the main active sites. Therefore, it is necessary to enhance the conductivity of the $\mathrm{TM}(\mathrm{OH})_{x}$, such as doping and hybrid with high conductive materials. For instance, the moderate Fe can effectively enhance conductivity of $\mathrm{Ni}(\mathrm{OH})_{2}$ to form $\mathrm{NiFe}$ LDHs [188]. For substrate, nickel foam is one of the best choic- es because of its 3D through-hole structure, high conductivity, good HER activity and high alkaline corrosion-resistance $[60,158,170,189]$. To further reduce the ohmic resistance between active materials and substrate, it better to directly grow active materials on substrate to avoid the addition of poor-conductivity binders [133,144,170,177,190].

\subsection{Stability}

Long-term stability is one of the most important parameters for HER and OER catalysts or electrodes. The essential reason of degradation is the reduction of exposed active sites, generally caused by the unstable structure of catalysts/electrodes and the coverage of poisons or bubbles. Kim and co-workers [158] directly electrodeposited cobalt iron hydroxide nanosheets on nickel foam ( $\mathrm{CoFe} / \mathrm{NF}$ ), which exhibited excellent stability. After $50 \mathrm{~h}$ stability test, although the polarization curve showed the near same HER activity, the nanosheets were also aggregated and the sharp edges are disturbed. At present, tremendous strategies have been applied for enhancing the stability of catalysts or electrodes for HER and OER, but for TM(OH) $)_{x}$ which exhibited its typical characteristics [149,158,162,177,187,191-194]. For instance, Malik et al. [191] found that the stability of CoPt@Co(OH) 2 array can be improved by magnetic field. As a result, the HER LSVs supported by an external magnet showed slight increase in overpotential of $4 \mathrm{mV}$ at a current density of $50 \mathrm{~mA} \mathrm{~cm}-2$ on the 1st and 5 th day of aging. However, when without an external magnet support, the degradation was very high. Because of the intrinsic magnetic property of the catalyst, the applied external magnetic field helped the magnetic CoPt NPs and the $\mathrm{Co}(\mathrm{OH})_{2}$ nanosheets to stuck on the CC substrate after the Nafion membrane being swelled during 5 days aging.

\section{Conclusion and outlook}

In summary, we introduced the structures and summarized recent developments of $\mathrm{TM}(\mathrm{OH})_{x}$ as assist-electrocatalysts and electrocatalysts for HER and water splitting. Recently, continuing breakthroughs have been gained for the construction of $\mathrm{TM}(\mathrm{OH})_{x}$ hybrids toward more efficient HER in alkaline conditions, which mainly focused on Ni-based hydroxides and LDHs hybridized with HER active materials. Owning to the synergistic effect between TM(OH $)_{x}$ and HER active materials, the HER electrode or electrocatalytic materials based on TM(OH) $x$ hybrids exhibit enhanced electrochemical performance. To further optimize the HER performance of the hybrid catalysts or electrodes, the "structure-function relationship" of the materials have been deeply studied, including the species, type of crystal structure, morphology and content of both $\mathrm{TM}(\mathrm{OH})_{x}$ and HER active materials. Benefiting to the proper adsorption energy to $\mathrm{OH}$ of $\mathrm{TM}(\mathrm{OH})_{x}$, especially for LDHs, it exhibits high OER activity. Hybridizing with HER active materials, it can act as bi-functional catalysts for overall water splitting. However, the process is too complicated to reach a high recognition mechanism except for the synergistic effect.

For large-scale application, the cost is a decisive factor to be 
considered, such as raw materials, manufacturing and maintenance. TM $(\mathrm{OH})_{X}$, assist-electrocatalyst for HER, is a great potential to reduce the cost of alkaline water electrolysis. After decorated a little of $\mathrm{TM}(\mathrm{OH})_{x}$ (e.g. $\mathrm{Ni}(\mathrm{OH})_{2}$ film with only thickness of $0.8 \mathrm{~nm}$ ), the HER activity of the catalysts can be obviously enhanced in alkaline condition, which can lower the overpotential to reduce the electricity cost. Besides of the little dosage, the raw materials (mainly refer to $\mathrm{Ni}$ ) are very cheap and the preparation methods (deposition, electrodeposition or hydrothermal method) are also very easy to operate. Furthermore, the stable structure of $\mathrm{TM}(\mathrm{OH})_{x}$ during HER operation can also reduce the cost of maintenance and materials replacement. Therefore, the $\mathrm{TM}(\mathrm{OH})_{x}$ with property of less dosage, cheap raw materials, simple method and stable performance is a proper candidate for large-scale water electrolysis for hydrogen production.

Although promising advances of highly efficient HER electrocatalysts designed by hybrid with $\mathrm{TM}(\mathrm{OH})_{x}$ have been made, there are still several challenges to be solved via this proposed strategy for a wide range of commercial applications.

(1) Mechanism. Although HER is one of the simplest electrochemical reactions, the processes of water reduction are still not well understood at molecular and electronic level. Especially for $\mathrm{TM}(\mathrm{OH})_{x}$ hybrids, which are difficult to be calculated via DFT owning to both the complicated structures and lack of sufficient experimental evidences. Additionally, the theory calculation is helpful to assisting with in situ characterization methods, such as spectroscopic measurements, however, it is also incapable of covering the reaction processes in real reaction conditions, including the changes of electrocatalysts, reactants, products and solvents.

(2) Electrode design. The whole HER includes the process of mass transfer, electron transfer and interface reaction, therefore, the design of electrodes must take all of these into consideration, such as enhancing the bubbles release, ions transfer, conductivity, electrocatalytic activity and durability. However, there are many inherent contradictions that cannot be avoided, e.g. the contradiction between high activity and good durability of catalysts, porous structure and mass transfer, the poor conductivity of $\mathrm{TM}(\mathrm{OH})_{x}$ and the enhanced activity by synergistic effect. Currently, the possible solution is try to balance the contradict relationship, but it is always very hard to consider all the contradictions. Therefore, the advanced electrode design to overcome the contradictions is desirable to enhance the activity and durability of electrodes.

(3) Electrolyte. Neutral media is a promising operating condition for HER in future application, because of the abundant seawater resource, benign nature, weak causticity, and low facility cost. However, there have been only a few researches on HER under neutral conditions, because HER proceeding in neutral media sustains more sluggish kinetics compared to that of alkaline and acidic conditions.

(4) Applications. For commercial applications, in order to reduce the operating cost and enhance the efficiency, the current density of the electrode is always over than $400 \mathrm{~mA} \mathrm{~cm}^{-2}$, which is much higher than that of common laboratory's test level of $10 \mathrm{~mA} \mathrm{~cm}-2$. Therefore, the polarization performance and stability of designed HER electrodes should be better to operate under higher current density and longer time (more than $500 \mathrm{~mA} \mathrm{~cm}^{-2}$ and $100 \mathrm{~h}$ ). In addition, reduce the fabrication and materials cost with simple, efficient and easy to large-scale preparation using low-cost and abundant materials is another vital role for applications.

\section{References}

[1] D. Stolten, B. Emonts, Hydrogen Science and Engineering: Materials, Processes, Systems and Technology, Wiley-VCH Verlag GmbH \& Co. KGaA, Weinheim, 2016.

[2] M. Ball, M. Wietschel, The Hydrogen Economy: Opportunities and Challenges, Cambridge University Press, New York, 2009.

[3] A. Godula-Jopek, Hydrogen Production by Electrolysis, Wiley-VCH Verlag GmbH \& Co. KGaA, Weinheim, 2015.

[4] J. Wang, F. Xu, H. Jin, Y. Chen, Y. Wang, Adv. Mater., 2017, 29, 1605838.

[5] S. Kumar, Clean Hydrogen Production Methods, Springer, Cham, 2015.

\section{Graphical Abstract}

Chin. J. Catal., 2020, 41: 574-591 doi: S1872-2067(19)63458-3

\section{Layered transition-metal hydroxides for alkaline hydrogen evolution reaction}

Qianfeng Liu, Erdong Wang*, Gongquan Sun*

Dalian Institute of Chemical Physics, Chinese Academy of Sciences;

University of Chinese Academy of Sciences

Although $\mathrm{TM}(\mathrm{OH})_{x}$ is poor in HER, when it decorated to HER active materials, the corresponding hybrid with synergistic effect can obviously promote their HER performance in alkaline electrolyte via boosting the tailor of water molecular.

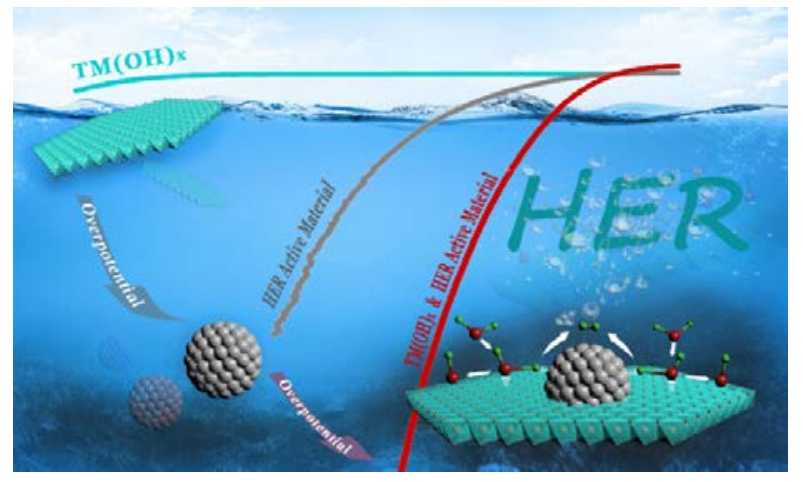


[6] S. A. Sherif, D. Yogi Goswami, E. K. Stefanakos, A. Steinfeld, Handbook of Hydrogen Energy, CRC Press, Boca Raton, 2014.

[7] K. H. Liu, H. X. Zhong, S. J. Li, Y. X. Duan, M. M. Shi, X. B. Zhang, J. M. Yan, Q. Jiang, Prog. Mater. Sci., 2018, 92, 64-111.

[8] Y. Shi, B. Zhang, Chem. Soc. Rev., 2016, 45, 1529-1541.

[9] Y. Zheng, Y. Jiao, M. Jaroniec, S. Z. Qiao, Angew. Chem. Int. Ed., 2015, 54, 52-65.

[10] J. Xie, Y. Xie, ChemCatChem, 2015, 7, 2568-2580.

[11] M. Gong, D. Y. Wang, C. C. Chen, B. J. Hwang, H. Dai, Nano Res., 2015, 9, 28-46.

[12] F. Lu, M. Zhou, Y. X. Zhou, X. H. Zeng, Small, 2017, 13, 1701931.

[13] M. I. Jamesh, J. Power Sources, 2016, 333, 213-236.

[14] L. A. Näslund, A. S. Ingason, S. Holmin, J. Rosen, J. Phys. Chem. C, 2014, 118, 15315-15323.

[15] Z. Wang, X. Ren, X. Shi, A. M. Asiri, L. Wang, X. Li, X. Sun, Q. Zhang, H. Wang, J. Mater. Chem. A, 2018, 6, 3864-3868.

[16] V. R. Stamenkovic, D. Strmcnik, P. P. Lopes, N. M. Markovic, Nat. Mater., 2016, 16, 57-69.

[17] J. R. McKone, B. F. Sadtler, C. A. Werlang, N. S. Lewis, H. B. Gray, ACS Catal., 2013, 3, 166-169.

[18] R. Patel, J. T. Park, M. Patel, J. K. Dash, E. B. Gowd, R. Karpoormath, A. Mishra, J. Kwak, J. H. Kim, J. Mater. Chem. A, 2018, 6, 12-29.

[19] H. Yin, Z. Tang, Chem. Soc. Rev., 2016, 45, 4873-4891.

[20] J. D. Benck, T. R. Hellstern, J. Kibsgaard, P. Chakthranont, T. F. Jaramillo, ACS Catal., 2014, 4, 3957-3971.

[21] X. Huang, Z. Zeng, H. Zhang, Chem. Soc. Rev., 2013, 42, 1934-1946.

[22] J. Xie, Y. Xie, Chem. Eur. J., 2016, 22, 3588-3598.

[23] Y. F. Zeng, Y. Y. Wang, G. Huang, C. Chen, L. L. Huang, R. Chen, S. Y. Wang, Chem. Commun., 2018, 54, 1465-1468.

[24] P. C. K. Vesborg, B. Seger, I. Chorkendorff, J. Phys. Chem. Lett., 2015, 6, 951-957.

[25] J. Zheng, Z. Zhuang, B. Xu, Y. Yan, W. Sheng, Sci. Adv., 2016, 2, e1501602.

[26] I. Ledezma-Yanez, W. D. Z. Wallace, P. Sebastián-Pascual, V. Climent, J. M. Feliu, M. T. M. Koper, Nat. Energy, 2017, 2, 17031.

[27] R. Subbaraman, D. Tripkovic, D. Strmcnik, K. C. Chang, M. Uchimura, A. P. Paulikas, V. Stamenkovic, N. M. Markovic, Science, 2011, 334, 1256-1260.

[28] S. Q. Liu, H. R. Wen, G. Ying, Y. W. Zhu, X. Z. Fu, R. Sun, C. P. Wong, Nano Energy, 2018, 44, 7-14.

[29] D. G. Evans, R. C. T. Slade, Struct Bond, 2005, 119, 1-87.

[30] M. Cao, X. He, J. Chen, C. Hu, Cryst. Growth Des., 2007, 7, 170-174.

[31] L. Xu, Y. S. Ding, C. H. Chen, L. Zhao, C. Rimkus, R. Joesten, S. L. Suib, Chem. Mater., 2008, 20, 308-316.

[32] R. S. McEwen, J. Phys. Chem., 1971, 75, 1782.

[33] D. S. Hall, B. R. MacDougall, D. J. Lockwood, C. Bock, Proc. Math. Phys. Eng. Sci., 2015, 471, 20140792.

[34] F. P. Kober, J. Electrochem. Soc., 1967, 114, 215.

[35] P. Oliva, J. Leonardi, J. F. Laurent, C. Delmas, J. J. Braconnier, M. Figlarz, F. Fievet, A. DeGuibert, J. Power Sources, 1982, 8, 229-255.

[36] J. Deng, M. R. Nellist, M. B. Stevens, C. Dette, Y. Wang, S. W. Boettcher, Nano Lett., 2017, 17, 6922-6926.

[37] S. Ida, D. Shiga, M. Koinuma, Y. Matsumoto, J. Am. Chem. Soc., 2008, 130, 14038-14039.

[38] L. Zhou, M. Shao, M. Wei, X. Duan, J. Energy Chem., 2017, 26, 1094-1106.

[39] L. Wang, C. Lin, D. K. Huang, J. M. Chen, L. Jiang, M. K. Wang, L. F. Chi, L. Shi, J. Jin, ACS Catal., 2015, 5, 3801-3806.

[40] H. Yin, S. Zhao, K. Zhao, A. Muqsit, H. Tang, L. Chang, H. Zhao, Y. Gao, Z. Tang, Nat. Commum., 2015, 6, 6430.

[41] L. Xu, Z. Wang, X. Chen, Z. K. Qu, F. Li, W. S. Yang, Electrochim. Acta, 2018, 260, 898-904.
[42] X. Li, F. C. Walsh, D. Pletcher, Phys. Chem. Chem. Phys., 2011, 13, 1162-1167.

[43] M. Z. Yu, S. Zhou, Z. Y. Wang, J. J. Zhao, J. S. Qiu, Nano Energy, 2018, 44, 181-190.

[44] S. M. Yin, W. G. Tu, Y. Sheng, Y. H. Du, M. Kraft, A. Borgna, R. Xu, Adv. Mater., 2018, 30, 1705106.

[45] H. Zhang, ACS Nano, 2015, 9, 9451-9469.

[46] H. S. Li, S. S. Wang, H. Sawada, G. G. D. Han, T. Samuels, C. S. Allen, A. I. Kirkland, J. C. Grossman, J. H. Warner, ACS Nano, 2017, 11, 3392-3403.

[47] H. Zhang, Y. L. Tong, J. Y. Xu, Q.Y. Lu, F. Gao, Chem. Eur. J., 2018, 24, 400-408.

[48] T. Wang, W. C. Xu, H. X. Wang, Electrochim. Acta, 2017, 257, 118-127.

[49] Y. M. Bi, Z. Cai, D. J. Zhou, Y. Tian, Q. Zhang, Q. Zhang, Y. Kuang, Y. P. Li, X. M. Sun, X. Duan, J. Catal., 2018, 358, 100-107.

[50] J. Chi, H. M. Yu, G. Jiang, J. Jia, B. W. Qin, B. L. Yi, Z. G. Shao, J. Mater. Chem. A, 2018, 6, 3397-3401.

[51] D. J. Zhou, Z. Cai, Y. M. Bi, W. L. Tian, M. Luo, Q. Zhang, Q. Zhang, Q. X. Xie, J. D. Wang, Y. P. Li, Y. Kuang, X. Duan, M. Bajdich, S. Siahrostami, X. M. Sun, Nano Res., 2018, 11, 1358-1368.

[52] Z. Yan, J. X. Gao, M. Liu, E. D. Wang, G. Q. Sun, Energy Technol., 2018, 6, 246-250.

[53] Y. H. Qian, Z. G. Hu, X. M. Ge, S. L. Yang, Y. W. Peng, Z. X. Kang, Z. L. Liu, J. Y. Lee, D. Zhao, Carbon, 2017, 111, 641-650.

[54] K. Chen, Y. Shen, Y. B. Zhang, Y. H. Lin, C. W. Nan, J. Power Sources, 2014, 249, 306-310.

[55] Q. Wang, D. Zhou, H. Yu, Z. Zhang, X. Bao, F. Zhang, M. Zhou, J. Electrochem. Soc., 2015, 162, A2362-A2366.

[56] Y. Ito, W. Cong, T. Fujita, Z. Tang, M. Chen, Angew. Chem. Int. Ed., 2015, 54, 2131-2136.

[57] H. Wang, X. B. Li, L. Gao, H. L. Wu, J. Yang, L. Cai, T. B. Ma, C. H. Tung, L. Z. Wu, G. Yu, Angew. Chem. Int. Ed., 2018, 57, 192-197.

[58] H. Li, M. Du, M. J. Mleczko, A. L. Koh, Y. Nishi, E. Pop, A. J. Bard, X. Zheng, J. Am. Chem. Soc., 2016, 138, 5123-5129.

[59] M. J. Wu, J. Z. Wu, J. Zhang, H. Chen, J. Z. Zhou, G. R. Qian, Z. P. Xu, Z. Du, Q. L. Rao, Catal. Sci. Technol., 2018, 8, 1207-1228.

[60] G. Chen, T. Wang, J. Zhang, P. Liu, H. Sun, X. Zhuang, M. Chen, X. Feng, Adv. Mater., 2018, 30, 1706279.

[61] Y. L. Hou, H. Kondoh, M. Shimojo, T. Kogure, T. Ohta, J. Phys. Chem. $B$, 2005, 109, 19094-19098.

[62] R. S. Jayashree, P. V. Kamath, J. Mater. Chem., 1999, 9, 961-963.

[63] X. Liu, R. Yi, N. Zhang, R. Shi, X. Li, G. Qiu, Chem. Asian J., 2008, 3, 732-738.

[64] Y. Liu, S. Liu, Y. Wang, Q. Zhang, L. Gu, S. Zhao, D. Xu, Y. Li, J. Bao, Z. Dai, J. Am. Chem. Soc., 2018, 140, 2731-2734.

[65] J. Zhang, J. Liu, L. Xi, Y. Yu, N. Chen, S. Sun, W. Wang, K. M. Lange, B. Zhang, J. Am. Chem. Soc., 2018, 140, 3876-3879.

[66] R. B. Wexler, J. M. P. Martirez, A. M. Rappe, J. Am. Chem. Soc., 2018, 140, 4678-4683.

[67] G. Centi, S. Perathoner, Microporous Mesoporous Mater., 2008, 107, 3-15.

[68] H. Y. Wang, G. Q. Shi, Acta Phys. Chim. Sin., 2018, 34, 22-35.

[69] M. A. Henderson, Surf. Sci. Rep., 2002, 46, 1-308.

[70] Z. X. Liang, H. S. Ahn, A. J. Bard, J. Am. Chem. Soc., 2017, 139, 4854-4858.

[71] Z. Xing, L. Gan, J. Wang, X. Yang, J. Mater. Chem. A, 2017, 5, 7744-7748.

[72] Z. Xing, C. Han, D. Wang, Q. Li, X. Yang, ACS Catal., 2017, 7, 7131-7135.

[73] L. Xie, X. Ren, Q. Liu, G. Cui, R. Ge, A. M. Asiri, X. Sun, Q. Zhang, L. Chen, J. Mater. Chem. A, 2018, 6, 1967-1970. 
[74] Z. Deng, J. Wang, Y. Nie, Z. Wei, J. Power Sources, 2017, 352, 26-33.

[75] L. Wang, Y. H. Zhu, Z. H. Zeng, C. Lin, M. Giroux, L. Jiang, Y. Han, J. Greeley, C. Wang, J. Jin, Nano Energy, 2017, 31, 456-461.

[76] H. C. Yang, C. H. Wang, F. Hu, Y. J. Zhang, H. Lu, Q. B. Wang, Sci. China Mater., 2017, 60, 1121-1128.

[77] B. Zhang, J. Liu, J. Wang, Y. Ruan, X. Ji, K. Xu, C. Chen, H. Wan, L. Miao, J. Jiang, Nano Energy, 2017, 37, 74-80.

[78] L. L. Chen, J. Y. Zhang, X. Ren, R. X. Ge, W. Q. Teng, X. P. Sun, X. M. Li, Nanoscale, 2017, 9, 16632-16637.

[79] L. Zhang, B. Liu, N. Zhang, M. Ma, Nano Res., 2017, 11, 323-333.

[80] R. Subbaraman, D. Tripkovic, K. C. Chang, D. Strmcnik, A. P. Paulikas, P. Hirunsit, M. Chan, J. Greeley, V. Stamenkovic, N. M. Markovic, Nat. Mater., 2012, 11, 550-557.

[81] N. Danilovic, R. Subbaraman, D. Strmcnik, K. C. Chang, A. P. Paulikas, V. R. Stamenkovic, N. M. Markovic, Angew. Chem. Int. Ed., 2012, 51, 12495-12498.

[82] F. J. Sarabia, P. Sebastian-Pascual, M. T. M. Koper, V. Climent, J. M. Feliu, ACS Appl. Mater. Interfaces, 2019, 11, 613-623.

[83] J. Wang, S. Mao, Z. Liu, Z. Wei, H. Wang, Y. Chen, Y. Wang, ACS Appl. Mater. Interfaces, 2017, 9, 7139-7147.

[84] Z. Weng, W. Liu, L. C. Yin, R. Fang, M. Li, E. I. Altman, Q. Fan, F. Li, H. M. Cheng, H. Wang, Nano Lett., 2015, 15, 7704-7710.

[85] L. Peng, X. Zheng, L. Li, L. Zhang, N. Yang, K. Xiong, H. Chen, J. Li, Z. Wei, Appl. Catal. B, 2019, 245, 122-129.

[86] H. Wu, T. Zhu, X. Lu, G. W. Ho, J. Mater. Chem. A, 2017, 5, 24153-24158.

[87] Z. Zhu, H. Yin, C. T. He, M. Al-Mamun, P. Liu, L. Jiang, Y. Zhao, Y. Wang, H. G. Yang, Z. Tang, D. Wang, X. M. Chen, H. Zhao, Adv. Mater., 2018, 30, e1801171.

[88] X. W. Yu, J. Zhao, L. R. Zheng, Y. Tong, M. Zhang, G. C. Xu, C. Li, J. Ma, G. Q. Shi, ACS Energy Lett., 2018, 3, 237-244.

[89] G. Wang, J. Parrondo, C. He, Y. Li, V. Ramani, J. Electrochem. Soc., 2017, 164, F1307-F1315.

[90] X. Zou, Y. Zhang, Chem. Soc. Rev., 2015, 44, 5148-5180.

[91] G. Yuan, B. Wen, Y. Hu, G. Zeng, W. Zhang, L. Wang, X. Zhang, Q. Wang, Int. J. Hydrogen Energy, 2019, 44, 14258-14265.

[92] E. Jung, H. Y. Park, A. Cho, J. H. Jang, H. S. Park, T. Yu, Appl. Catal. $B, \mathbf{2 0 1 8}, 225,238-242$.

[93] V. Stamenkovic, B. S. Mun, K. J. J. Mayrhofer, P. N. Ross, N. M. Markovic, J. Rossmeisl, J. Greeley, J. K. Nørskov, Angew. Chem. Int. Ed., 2006, 45, 2897-2901.

[94] H. Wei, K. Huang, L. Zhang, B. Ge, D. Wang, J. Lang, J. Ma, D. Wang, S. Zhang, Q. Li, R. Zhang, N. Hussain, M. Lei, L. M. Liu, H. Wu, Angew. Chem. Int. Ed., 2018, 57, 3354-3359.

[95] H. Wei, K. Huang, D. Wang, R. Zhang, B. Ge, J. Ma, B. Wen, S. Zhang, Q. Li, M. Lei, C. Zhang, J. Irawan, L. M. Liu, H. Wu, Nat. Commun., 2017, 8, 1490.

[96] N. Becknell, Y. Son, D. Kim, D. Li, Y. Yu, Z. Niu, T. Lei, B.T. Sneed, K. L. More, N. M. Markovic, V. R. Stamenkovic, P. Yang, J. Am. Chem. Soc., 2017, 139, 11678-11681.

[97] M. Favaro, C. Valero-Vidal, J. Eichhorn, F. M. Toma, P. N. Ross, J. Yano, Z. Liu, E. J. Crumlin, J. Mater. Chem. A, 2017, 5, 11634-11643.

[98] J. Ismail, M. F. Ahmed, P. V. Kamath, J. Power Sources, 1991, 36, 507-516.

[99] P. Elumalai, H. N. Vasan, N. Munichandraiah, J. Power Sources, 2001, 93, 201-208.

[100] Z. F. Huang, J. Wang, Y. C. Peng, C. Y. Jung, A. Fisher, X. Wang, Adv. Energy Mater., 2017, 7, 1700544.

[101] Y. Kou, J. Liu, Y. B. Li, S. X. Qu, C. Ma, Z. S. Song, X. P. Han, Y. D. Deng, W. B. Hu, C. Zhong, ACS Appl. Mater. Interfaces, 2018, 10,
796-805.

[102] D. Strmcnik, P. P. Lopes, B. Genorio, V. R. Stamenkovic, N. M. Markovic, Nano Energy, 2016, 29, 29-36.

[103] Y. Wu, J. Luo, Acta Phys. Chim. Sin., 2016, 32, 2745-2752.

[104] J. Greeley, T. F. Jaramillo, J. Bonde, I. B. Chorkendorff, J. K. Norskov, Nat. Mater., 2006, 5, 909-913.

[105] Y. Kuang, G. Feng, P.S. Li, Y. M. Bi, Y. P. Li, X. M. Sun, Angew. Chem. Int. Ed., 2016, 55, 693-697.

[106] L. Zhang, K. Xiong, Y. Nie, X. Wang, J. Liao, Z. Wei, J. Power Sources, 2015, 297, 413-418.

[107] R. Kavian, S. I. Choi, J. Park, T. Liu, H. C. Peng, N. Lu, J. Wang, M. J. Kim, Y. Xia, S. W. Lee, J. Mater. Chem. A, 2016, 4, 12392-12397.

[108] A. Maizelis, B. Bairachniy, Mater. Today Proc., 2019, 6, 227-231.

[109] Z. W. Yin, F. Y. Chen, Electrochim. Acta, 2014, 117, 84-91.

[110] H. Yuan, R. R. Lunt, J. I. Thompson, R. Y. Ofoli, ChemElectroChem, 2017, 4, 241-245.

[111] S. Tao, F. Yang, J. Schuch, W. Jaegermann, B. Kaiser, ChemSusChem, 2018, 11, 948-958.

[112] Z. Yuan, S.-M. Bak, P. Li, Y. Jia, L. Zheng, Y. Zhou, L. Bai, E. Hu, X.-Q. Yang, Z. Cai, Y. Sun, X. Sun, ACS Energy Lett., 2019, 4, 1412-1418.

[113] Q. Liu, Z. Yan, E. Wang, S. Wang, G. Sun, Int. J. Hydrog. Energy, 2017, 42, 23045-23053.

[114] M. Chhetri, S. Sultan, C. N. R. Rao, Proc. Natl. Acad. Sci. USA, 2017, 114, 8986-8990.

[115] X. Chia, A. Y. Eng, A. Ambrosi, S. M. Tan, M. Pumera, Chem. Rev., 2015, 115, 11941-11966.

[116] Z. Xu, W. Li, Y. Yan, H. Wang, H. Zhu, M. Zhao, S. Yan, Z. Zou, ACS Appl. Mater. Interfaces, 2018, 10, 22102-22109.

[117] L. Zhang, I. S. Amiinu, X. Ren, Z. Liu, G. Du, A. M. Asiri, B. Zheng, X. Sun, Inorg. Chem., 2017, 56, 13651-13654.

[118] Y. M. Chen, R. X. Wu, P. P. Jiang, G. Bian, L. G. Kong, Y. M. Dong, RSC Adv., 2015, 5, 60674-60680.

[119] Q. Ma, C. Hu, K. Liu, S.-F. Hung, D. Ou, H. M. Chen, G. Fu, N. Zheng, Nano Energy, 2017, 41, 148-153.

[120] X. Zhang, S. Zhu, L. Xia, C. Si, F. Qu, F. Qu, Chem. Commun., 2018, 54, 1201-1204.

[121] M. Gao, L. Chen, Z. Zhang, X. Sun, S. Zhang, J. Mater. Chem. A, 2018, 6, 833-836.

[122] S. Baranton, C. Coutanceau, Appl. Catal. B, 2013, 136, 1-8.

[123] J. Bai, Q. Sun, Z. Wang, C. Zhao, J. Electrochem. Soc., 2017, 164, H587-H592.

[124] W. Y. Lim, Y. F. Lim, G. W. Ho, J. Mater. Chem. A, 2017, 5, 919-924.

[125] C. A. Melendres, M. Pankuch, J. Electroanal. Chem., 1992, 333, 103-113.

[126] R. Sandoval, R. Schrebler, H. Gomez, J. Electroanal. Chem., 1986, 210, 287-294.

[127] D. S. Hall, C. Bock, B. R. MacDougall, J. Electrochem. Soc., 2013, 160, F235-F243.

[128] D. Floner, C. Lamy, J. M. Leger, Surf. Sci., 1990, 234, 87-97.

[129] L. Zhang, P. F. Liu, Y. H. Li, C. W. Wang, M. Y. Zu, H. Q. Fu, X. H. Yang, H. G. Yang, ACS Catal., 2018, 8, 5200-5205.

[130] J. Hu, C. Zhang, L. Jiang, H. Lin, Y. An, D. Zhou, M. K. H. Leung, S. Yang, Joule, 2017, 1, 383-393.

[131] Y. Yang, W. Zhang, Y. Xiao, Z. Shi, X. Cao, Y. Tang, Q. Gao, Appl. Catal. B, 2019, 242, 132-139.

[132] J. Bai, Q. Sun, M. Zhou, L. Wang, Y. Shen, Y. Ma, Z. Wang, C. Zhao, J. Electrochem. Soc., 2018, 165, H866-H871.

[133] J. Lee, G. H. Lim, B. Lim, Chem. Phys. Lett., 2016, 644, 51-55.

[134] A. A. Ensafi, A. Nabiyan, M. Jafari-Asl, M. Dinari, H. Farrokhpour, B. Rezaei, Energy, 2016, 116, 1087-1096.

[135] J. X. Feng, L. X. Ding, S. H. Ye, X. J. He, H. Xu, Y. X. Tong, G. R. Li, Adv. Mater., 2015, 27, 7051-7057. 
[136] X. Tong, D. Wu, C. Zhang, K. Lian, D. Xiong, S. Xu, Y. Zhu, R. Qi, R. Huang, L. Wang, P. K. Chu, J. Mater. Chem. A, 2017, 5, 2629-2639.

[137] Y. Liu, B. Dong, Y. Liu, C. Liu, AIP Conf. Proc., 2017, 1794, 020039/1-020039/4.

[138] B. M. Hunter, H. B. Gray, A. M. Muller, Chem. Rev., 2016, 116, 14120-14136.

[139] C. Tang, H. F. Wang, Q. Zhang, Acc. Chem. Res., 2018, 51, 881-889.

[140] Y. P. Zhu, C. X. Guo, Y. Zheng, S. Z. Qiao, Acc. Chem. Res., 2017, 50, 915-923.

[141] S. K. Mazloomi, N. Sulaiman, Renew. Sustain. Energy Rev., 2012, 16, 4257-4263.

[142] N. K. Chaudhari, H. Jin, B. Kim, K. Lee, Nanoscale, 2017, 9, 12231-12247.

[143] Z. Wu, Z. Wang, F. Geng, ACS Appl. Mater. Interfaces, 2018, 10, 8585-8593.

[144] Y. Rao, Y. Wang, H. Ning, P. Li, M. Wu, ACS Appl. Mater. Interfaces, 2016, 8, 33601-33607.

[145] X. Du, J. Huang, J. Zhang, Y. Yan, C. Wu, Y. Hu, C. Yan, T. Lei, W. Chen, C. Fan, J. Xiong, Angew. Chem. Int. Ed., 2019, 58, 4484-4502.

[146] J. Suntivich, H. A. Gasteiger, N. Yabuuchi, H. Nakanishi, J. B. Goodenough, Y. Shao-Horn, Nat. Chem., 2011, 3, 546-550.

[147] J. Suntivich, K. J. May, H. A. Gasteiger, J. B. Goodenough, Y. Shao-Horn, Science, 2011, 334, 1383-1385.

[148] C. S. Lim, C. K. Chua, Z. Sofer, K. Klímová, C. Boothroyd, M. Pumera, J. Mater. Chem. A, 2015, 3, 11920-11929.

[149] X. H. Sun, Q. Shao, Y. C. Pi, J. Guo, X. Q. Huang, J. Mater. Chem. A, 2017, 5, 7769-7775.

[150] J. Liu, J. S. Wang, B. Zhang, Y. J. Ruan, L. Lv, X. Ji, K. Xu, L. Miao, J. J. Jiang, ACS Appl. Mater. Interfaces, 2017, 9, 15364-15372.

[151] Z. Q. Wang, S. Zeng, W. H. Liu, X. W. Wang, Q. W. Li, Z.G. Zhao, F. X. Geng, ACS Appl. Mater. Interfaces, 2017, 9, 1488-1495.

[152] H. Zhang, X. Li, A. Hähnel, V. Naumann, C. Lin, S. Azimi, S. L. Schweizer, A. W. Maijenburg, R. B. Wehrspohn, Adv. Funct. Mater., 2018, 28, 1706847.

[153] K. N. Dinh, P. L. Zheng, Z. F. Dai, Y. Zhang, R. Dangol, Y. Zheng, B. Li, Y. Zong, Q. Y. Yan, Small, 2018, 14, 1703257.

[154] Q. Liu, H. Wang, X. Wang, R. Tong, X. Zhou, X. Peng, H. Wang, H. Tao, Z. Zhang, Int. J. Hydrogen Energy, 2017, 42, 5560-5568.

[155] A. L. Wang, H. Xu, G. R. Li, ACS Energy Lett., 2016, 1, 445-453.

[156] M. Abu Sayeed, A. P. O'Mullane, J. Mater. Chem. A, 2017, 5, 23776-23784.

[157] Y. Cho, J. Lee, T. T. H. Nguyen, J. W. Bae, T. Yu, B. Lim, J. Ind. Eng. Chem., 2016, 37, 175-179.

[158] P. Babar, A. Lokhande, H. H. Shin, B. Pawar, M. G. Gang, S. Pawar, J. H. Kim, Small, 2018, 14, 1702568.

[159] Q. Zhao, J. Yang, M. Liu, R. Wang, G. Zhang, H. Wang, H. Tang, C. Liu, Z. Mei, H. Chen, F. Pan, ACS Catal., 2018, 8, 5621-5629.

[160] A. Grimaud, K. J. May, C. E. Carlton, Y. L. Lee, M. Risch, W. T. Hong, J. Zhou, Y. Shao-Horn, Nat. Commun., 2013, 4, 2439.

[161] S. L. Zhao, Y. Wang, J. C. Dong, C. T. He, H. J. Yin, P. F. An, K. Zhao, X. F. Zhang, C. Gao, L. J. Zhang, J. W. Lv, J. X. Wang, J. Q. Zhang, A. M. Khattak, N. A. Khan, Z. X. Wei, J. Zhang, S. Q. Liu, H. J. Zhao, Z. Y. Tang, Nat. Energy, 2016, 1, 16184.

[162] T. Tang, W. J. Jiang, S. Niu, N. Liu, H. Luo, Y. Y. Chen, S. F. Jin, F. Gao, L. J. Wan, J. S. Hu, J. Am. Chem. Soc., 2017, 139, 8320-8328.

[163] T. Yoon, K. S. Kim, Adv. Funct. Mater., 2016, 26, 7386-7393.

[164] P. F. Liu, S. Yang, B. Zhang, H. G. Yang, ACS Appl. Mater. Interfaces, 2016, 8, 34474-34481.

[165] C. Hu, L. Zhang, Z. J. Zhao, A. Li, X. Chang, J. Gong, Adv. Mater., 2018, 30, e1705538.
[166] Y. Jia, L. Z. Zhang, G. P. Gao, H. Chen, B. Wang, J. Z. Zhou, M. T. Soo, M. Hong, X. C. Yan, G. R. Qian, J. Zou, A. J. Du, X. D. Yao, Adv. Mater., 2017, 29, 1700017.

[167] L. Yu, H. Zhou, J. Sun, F. Qin, F. Yu, J. Bao, Y. Yu, S. Chen, Z. Ren, Energy Environ. Sci., 2017, 10, 1820-1827.

[168] S. Niu, W. J. Jiang, T. Tang, Y. Zhang, J. H. Li, J. S. Hu, Adv. Sci., 2017, 4, 1700084.

[169] L. Tao, Y. Li, M. Li, G. Gao, X. Xiao, M. Wang, X. Jiang, X. Lv, Q. Li, S. Zhang, Z. Zhao, C. Zhao, Y. Shen, J. Phys. Chem. C, 2017, 121, 25888-25897.

[170] W. J. Liu, J. Bao, M. L. Guan, Y. Zhao, J. B. Lian, J. X. Qiu, L. Xu, Y. P. Huang, J. Qian, H. M. Li, Dalton Trans., 2017, 46, 8372-8376.

[171] U. K. Sultana, J. D. Riches, A. P. O'Mullane, Adv. Funct. Mater., 2018, 28, 1804361.

[172] M. Y. Gao, C. B. Sun, H. Lei, J. R. Zeng, Q. B. Zhang, Nanoscale, 2018, 10, 17546-17551.

[173] Q. Yang, Q. Xu, H. L. Jiang, Chem. Soc. Rev., 2017, 46, 4774-4808.

[174] E. Havakeshian, H. Salavati, M. Taei, F. Hasheminasab, M. Seddighi, Chem. Phys. Lett., 2018, 693, 46-54.

[175] Z. C. Xing, L. F. Gan, J. Wang, X. R. Yang, J. Mater. Chem. A, 2017, 5, 7744-7748.

[176] M. Taei, E. Havakeshian, F. Hasheminasab, J. Electroanal. Chem., 2018, 808, 75-81.

[177] S. Dutta, A. Indra, Y. Feng, T. Song, U. Paik, ACS Appl. Mater. Interfaces, 2017, 9, 33766-33774.

[178] Q. Q. Chen, C. C. Hou, C. J. Wang, X. Yang, R. Shi, Y. Chen, Chem. Commun., 2018, 54, 6400-6403.

[179] Z. Qiu, C. W. Tai, G. A. Niklasson, T. Edvinsson, Energy Environ. Sci., 2019, 12, 572-581.

[180] Q. Che, Q. Li, Y. Tan, X. Chen, X. Xu, Y. Chen, Appl. Catal. B, 2019 246, 337-348.

[181] S. Debata, S. Banerjee, P. K. Sharma, Electrochim. Acta, 2019, 303, 257-267.

[182] S. Hao, L. Chen, C. Yu, B. Yang, Z. Li, Y. Hou, L. Lei, X. Zhang, ACS Energy Lett., 2019, 4, 952-959.

[183] D. Li, B. Zhang, Y. Li, R. Chen, S. Hu, H. Ni, Electrochem. Commun., 2019, 101, 23-27.

[184] M. Li, L. Tao, X. Xiao, X. Jiang, M. Wang, Y. Shen, ACS Sustain. Chem. Eng., 2019, 7, 4784-4791.

[185] Z. Lu, W. Zhu, X. Yu, H. Zhang, Y. Li, X. Sun, X. Wang, H. Wang, J. Wang, J. Luo, X. Lei, L. Jiang, Adv. Mater., 2014, 26, 2683-2687.

[186] Z. Lu, Y. Li, X. Lei, J. Liu, X. Sun, Mater. Horiz., 2015, 2, 294-298.

[187] T. Tang, W. J. Jiang, S. Niu, N. Liu, H. Luo, Q. Zhang, W. Wen, Y. Y. Chen, L. B. Huang, F. Gao, J. S. Hu, Adv. Funct. Mater., 2018, 28, 1704594.

[188] L. Trotochaud, S. L. Young, J. K. Ranney, S. W. Boettcher, J. Am. Chem. Soc., 2014, 136, 6744-6753.

[189] X. L. Zhu, C. Tang, H. F. Wang, B. Q. Li, Q. Zhang, C. Y. Li, C. H. Yang, F. Wei, J. Mater. Chem. A, 2016, 4, 7245-7250.

[190] S. Anantharaj, K. Karthick, M. Venkatesh, T. V. S. V. Simha, A. S. Salunke, L. Ma, H. Liang, S. Kundu, Nano Energy, 2017, 39, 30-43.

[191] B. Malik, S. Anantharaj, K. Karthick, D. K. Pattanayak, S. Kundu, Catal. Sci. Technol., 2017, 7, 2486-2497.

[192] F. S. Zhang, J. W. Wang, J. Luo, R. R. Liu, Z. M. Zhang, C. T. He, T. B. Lu, Chem. Sci., 2018, 9, 1375-1384.

[193] Q. Chen, R. Wang, M. H. Yu, Y. X. Zeng, F. Q. Lu, X. J. Kuang, X. H. Lu, Electrochim. Acta, 2017, 247, 666-673.

[194] R. Zhang, H. Wei, W. Si, G. Ou, C. Zhao, M. Song, C. Zhang, H. Wu, Materials, 2017, 10, 15/1-15/8.

[195] B. Sidhureddy, A. R. Thiruppathi, A. C. Chen, J. Electroanal. Chem., 2017, 794, 28-35. 
[196] Y. Zhang, Q. Shao, Y. C. Pi, J. Guo, X. Q. Huang, Small, 2017, 13, 1700355 .
[197] P. Babar, A. Lokhande, V. Karade, B. Pawar, M. G. Gang, S. Pawar, J. H. Kim, ACS Sustain. Chem. Eng., 2019, 7, 10035-10043.

\title{
层状过渡金属氢氧化物应用于碱性氢气析出反应
}

\author{
刘乾锋 ${ }^{\mathrm{a}, \mathrm{b}}$, 王二东 ${ }^{\mathrm{a}, *}$, 孙公权 ${ }^{\mathrm{a}, \#}$ \\ a 中国科学院大连化学物理研究所, 洁净能源国家实验室, 燃料电池研究部, 辽宁大连116023 \\ $\mathrm{b}$ 中国科学院大学, 北京 100049
}

摘要: 氢气因为其高质量比活性, 环境友好等特点, 被公认为是一种很有希望替代化石能源的可再生能源. 其中, 碱性条件 电解水被认为是可大规模生产氢气的技术之一. 但氢气析出反应在碱性条件反应速率缓慢, 为提升氢气析出反应速率, 因 此研究者们设计和制备了大量的材料. 本文归纳了有效促进碱性条件氢气析出反应速率的关键材料一一层状过渡金属氢 氧化物的重要研究进展. 首先, 基于过渡金属氢氧化物的结构, 阐述了过渡金属氢氧化物与氢气析出反应活性材料间的协 同催化机理. 接着, 以提升协同催化作用为中心, 归纳了基于过渡金属氢氧化物的氢气析出反应催化剂和电极的最近研究 进展, 分别包含过渡金属氢氧化物和氢气析出反应活性材料的种类、结构、形貌及其相互作用. 此外, 本文从高活性和长 寿命的催化剂和电极设计出发, 归纳了最近基于过渡金属氢氧化物的催化剂和电极在水分解领域的进展. 最后, 本文总结 和展望了电解水制氢技术的未来应用和发展中不可避免的一些问题与挑战.

目前, 应用于氢析出反应的过渡金属氢氧化物主要集中于镍基、钴基和铁基氢氧化物和其双金属氢氧化物, 为层状水 滑石结构. 因为上述过渡金属氢氧化物弱的氢吸附, 所以其析氢活性非常低. 但是过渡金属氢氧化物对氢氧根的吸附能力 强, 其与析氢活性材料复合后能形成协同作用, 提升氢析出反应速率. 具体而言, 当水吸附在析氢活性材料和过渡金属氢 氧化物的界面处时, 水的氢原子端吸附在析氢活性材料侧, 而水的另一端——氢氧根, 吸附在过渡金属氢氧化物侧, 这样的 吸附方式对水的分解具有很强的剪切作用, 从而加快碱性氢析出反应的决速步——水分子分解, 加快析氢反应速率. 为深 入理解协同作用和进一步提升协同作用效果, 研究者对过渡金属氢氧化物和对应的复合析氢活性材料的种类、结构、形貌 和含量, 进行了系统深入的研究. 结果显示, 氢氧化镍和氢氧化钴能明显促进氢析出反应, 其中, 氢氧化镍更具优势. 此外, 过渡金属氢氧化物具有较好氧析出活性, 所以合适的过渡金属氢氧化物与析氢活性材料复合后, 可制备氢析出反应和氧析 出反应的双功能催化剂和电极.

关键词: 过渡金属氢氧化物; 氢气析出反应; 水分解; 电催化; 协同作用

收稿日期: 2019-09-30. 接受日期: 2019-10-22. 出版日期: 2020-04-05.

*通讯联系人. 电话/传真: (0411)84379216; 电子邮箱: edwang@dicp.ac.cn

\#通讯联系人. 电话: (0411)84379240; 传真: (0411)84379600; 电子邮箱: gqsun@dicp.ac.cn

基金来源：国家重点研发计划(2017YFC0306403); 中国科学院战略性先导科技专项(XDA09030104, XDA22010601); 中国科学院 青年创新促进会.

本文的电子版全文由Elsevier出版社在ScienceDirect上出版(http://www.sciencedirect.com/science/journal/18722067). 